\title{
Trinidad and Tobago: Financial System Stability Assessment, including Reports on the Observance of Standards and Codes on the following topics, Banking Supervision, and Payment Systems
}

This Financial System Stability Assessment on Trinidad and Tobago was prepared by a staff team of the International Monetary Fund and the World Bank as background documentation for the periodic consultation with the member country. It is based on the information available at the time it was completed on October 26, 2005. The views expressed in this document are those of the staff team and do not necessarily reflect the views of the government of Trinidad and Tobago or the Executive Board of the IMF.

The policy of publication of staff reports and other documents by the IMF allows for the deletion of market-sensitive information.

To assist the IMF in evaluating the publication policy, reader comments are invited and may be sent by e-mail to publicationpolicy@imf.org.

Copies of this report are available to the public from

International Monetary Fund $\bullet$ Publication Services

700 19th Street, N.W. • Washington, D.C. 20431

Telephone: (202) $6237430 \bullet$ Telefax: (202) 6237201

E-mail: publications@imf.org • Internet: http://www.imf.org

Price: $\$ 15.00$ a copy

\section{International Monetary Fund} Washington, D.C. 



\title{
INTERNATIONAL MONETARY FUND
}

\section{Trinidad and Tobago}

\section{Financial System Stability Assessment}

\author{
Prepared by the Monetary and Financial Systems and Western Hemisphere Departments \\ Approved by Ulrich Baumgartner and Anoop Singh
}

October 26, 2005

\begin{abstract}
The financial stability assessment is based on the work of two Financial Sector Assessment Program (FSAP) missions that visited Trinidad and Tobago (TTO) in February and May 2005. The mission teams comprised: Udaibir S. Das (Mission Chief, IMF), Anjali Kumar (Deputy Mission Chief, World Bank), Scott Roger, Marco Espinosa, Jay Surti, Wendell Samuel, and Ms. Renee Cárdenas (all IMF); Peter Kyle, Massimo Cirasino, Bikki Randhawa, Inessa Love, and Corinne N'Daw-Amany, (all World Bank); Colin Miles (Bank of England), Kim Leng Chua (Monetary Authority of Singapore), Andy McNabb (UK Financial Services Authority), Jeff Carmichael (formerly Australian Prudential Regulatory Authority), and Don McIssac (formerly Canada's Office of the Superintendent of Financial Institutions). The main FSAP findings, which were discussed further with the authorities during the Article IV Consultation mission in July 2005 are:
\end{abstract}

- TTO's financial system is relatively large and structurally complex, demonstrating both sophistication and oligopolistic concentration. Although it does not appear to be vulnerable to immediate-term macroeconomic shocks, its risk profile has evolved. Over the last decade, the contractual savings sector has replaced banking as the single largest segment and a few regionally active, mixed activities conglomerates have become dominant.

- Stress tests and the assessment of compliance with Basel Core Principles indicate that the banking system is well capitalized and profitable, but is vulnerable to the potential macroeconomic impact of a sharp fall in energy prices. Sharp reversals in equity prices may adversely affect the insurance and pension sectors. Rising levels of connected exposures in some conglomerates have increased the risk of contagion. The system also appears to have acquired some reputational and financial risk through the concentration of investments in the CARICOM area.

- Given a regionally active, complex financial system, the segmentation of the core legislative, regulatory, and supervisory framework suggests the urgency of reform in these areas. Changes are required to (i) facilitate consolidated supervision and regulation of financial institutions, including their cross-border activities; and (ii) transform the supervisory structure, including financial reporting, into a more integrated and risk-based framework. Financial institutions' own risk management techniques are also lagging behind their evolving cross-market and cross-border intermediation patterns.

- The authorities are aware of these shortcomings and have embarked on an ambitious reform program with a view to establishing Port of Spain as a regional financial center by 2020. They have requested post-FSAP technical support in implementation of the ongoing reforms and steps outlined in the FSAP.

The main authors of this report are Messrs. Das, Roger, Espinosa, and Surti.

FSAPs are designed to assess the stability of the financial system as a whole and not that of individual institutions. They have been developed to help countries identify and remedy weaknesses in their financial sector structure, thereby enhancing their resilience to macroeconomic shocks and cross-border contagion. FSAPs do not cover risks that are specific to individual institutions such as asset quality, operational or legal risks, or fraud. 
Glossary

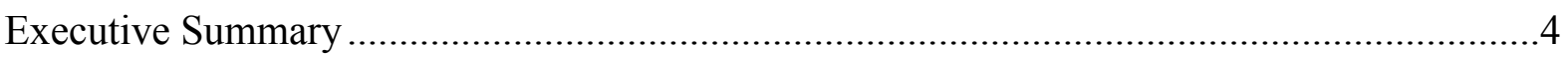

I. Macroeconomic Developments, Financial Structure, and Regulatory Context ................... 7

A. Macroeconomic Developments.......................................................................... 7

B. Financial System Structure......................................................................... 8

C. Financial Regulation and Supervision............................................................. 12

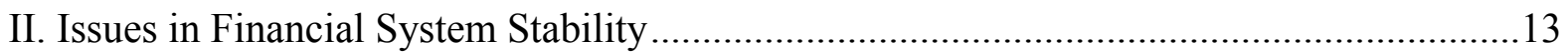

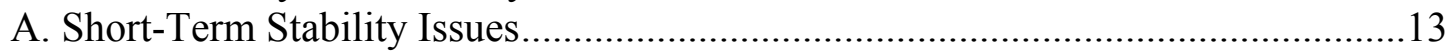

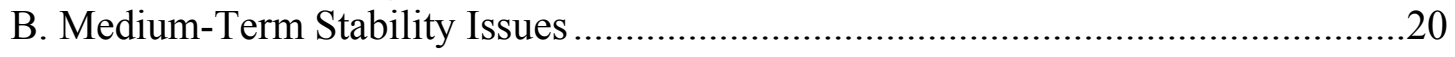

III. Medium-Term Development and Structural Issues .................................................22

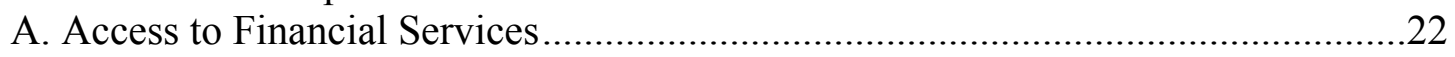

B. Securities Markets, Insurance, and Pensions ...................................................23

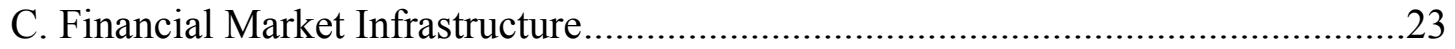

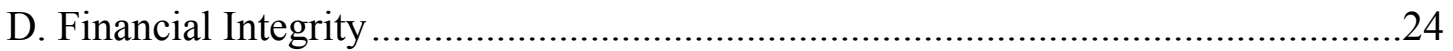

Tables

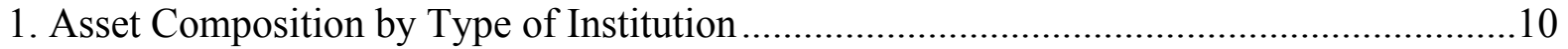

2. Share of Conglomerates in the Financial System ......................................................... 10

3. Trinidad and Tobago: Geographic Exposure of Financial System Assets ........................12

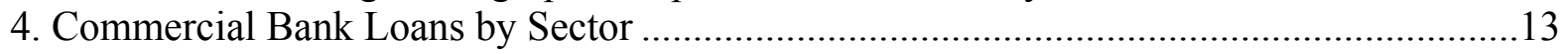

5. Summary of Stress Tests and Main Results................................................................. 16

6. Banking Sector Regulatory Compliance Indicators...................................................17

Figures

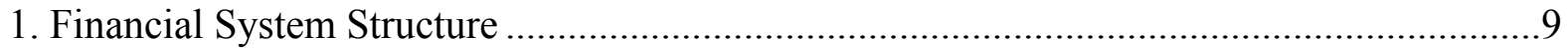

2a Conglomerates' Share in the Assets of Licensed Financial Institutions, 2003 .................11

2b. Conglomerates' Share in the Life Insurance Business, 2003 ........................................11

3. Credit and Equities Markets......................................................................................14

4. Monthly Price and Earnings Data for the TTSE, by Sector............................................14

Boxes

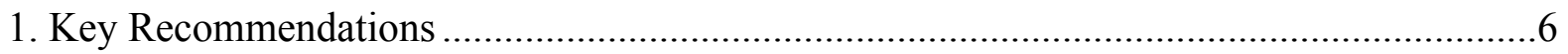

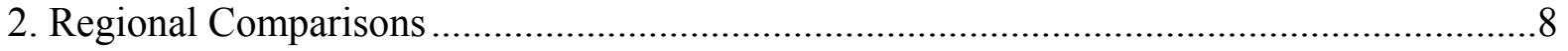

3. Challenges in Consolidated Supervision ............................................................. 18

Appendices

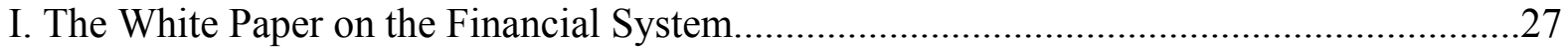

II. Stress Testing the Trinidad and Tobago Financial System ..........................................29

Annex

Observance of Standards and Codes — Summary Assessments.......................................31 


\section{GLOSSARY}

$\begin{array}{ll}\text { ACH } & \text { Automated Clearinghouse } \\ \text { AML/CFT } & \text { Anti-Money Laundering and Combating the Financing of Terrorism } \\ \text { CAR } & \text { Capital adequacy ratio } \\ \text { CBTT } & \text { Central Bank of Trinidad and Tobago } \\ \text { CFATF } & \text { Caribbean Financial Action Task Force } \\ \text { CARICOM } & \text { Caribbean Community } \\ \text { DIC } & \text { Deposit Insurance Corporation } \\ \text { ELA } & \text { Emergency liquidity assistance } \\ \text { FIA } & \text { Financial Institutions Act } \\ \text { FSAP } & \text { Financial Sector Assessment Program } \\ \text { GSS } & \text { Custody Settlement System for Government Securities } \\ \text { HMB } & \text { Home Mortgage Bank } \\ \text { HSF } & \text { Heritage and Stabilization Fund } \\ \text { IA } & \text { Insurance Act } \\ \text { LFI } & \text { Licensed financial institution } \\ \text { NIB } & \text { National Insurance Board } \\ \text { OBA } & \text { Open bank assistance } \\ \text { PPS } & \text { Policyholder protection scheme } \\ \text { RTGS } & \text { Real Time Gross Settlement } \\ \text { TTO } & \text { Trinidad and Tobago } \\ \text { TTSE } & \text { Trinidad and Tobago Stock Exchange } \\ \text { TTSEC } & \text { Trinidad and Tobago Securities and Exchange Commission } \\ \text { SIA } & \text { Securities Industry Act } \\ \text { UTC } & \text { Unit Trust Corporation } \\ \text { White Paper } & \text { White Paper on the Financial System of Trinidad and Tobago }\end{array}$




\section{EXECUTIVE SUMMARY}

Trinidad and Tobago's (TTO) financial system is large and complex and has witnessed rapid structural change over the last decade. Befitting a fast growing, middle-income economy, contractual savings has replaced banking as the largest segment of the financial system. Strong ownership and transactional linkages have developed among insurance companies, banks, securities firms, and other sectors, a process facilitated by the dominance of internationally active, mixed activities conglomerates seeking new liquidity sources and investment opportunities. In consequence, the traditional division among banking, insurance, and other financial products and services has become less meaningful in TTO from the viewpoint of potential systemic risks and financial stability.

The immediate-term macroeconomic risks to the different segments of the financial system appear low. However, the overall risk profile of the financial system has evolved and needs closer monitoring. Although the macroprudential condition of the commercial banks appears sound, their financial linkages with nonbank intermediaries, particularly insurers, potentially expose them to contagion. In this context, the recent rapid increases in the nonbanks' exposures to the domestic equities market and to regional economies give pause for concern. Mutual investment by banks and insurers in each other's equity also appears to be on the rise within some conglomerates, thereby increasing potential contagion risk at a systemic level. Systemic risk is also exacerbated by the need to strengthen market-based discipline and risk management practices.

Critical gaps remain in the overall legal, regulatory and supervisory structure. Despite considerable strengthening of banking supervision, the current framework is not yet fully aligned with the evolution of the financial system. Financial sector laws do not endow regulators with sufficient formal powers to oversee cross-market and cross-border activities, and issues such as prudential and market conduct aspects of the insurance business. Moreover, a significant part of the financial system, including statutory corporations, credit unions, and mutual and pension funds, is beyond the purview of ongoing risk-based supervisory oversight. Improvements in financial supervisory reporting and the introduction of uniform actuarial standards for determining insurance liabilities are needed to ensure the comparability of insurers' financial statements.

Stress tests suggest that near-term systemic risks are limited owing to a liquid and well-capitalized banking system and good liquidity positions of the insurers. The banks appear resilient to a majority of traditional credit and market risks. The system remains vulnerable, however, to the potential domestic impact of a large decline in energy prices on default rates on banks' lending portfolios. Equity and property price shocks, especially as part of a downturn in general economic activity, could lead to problems in the contractual savings sector.

The impact of a significant deterioration in external asset values is more difficult to assess. Limited consolidated reporting and supervisory data precludes a comprehensive analysis of regional exposures. Important missing information includes the cross-border net 
exposure of domestic insurers and pension funds investing and lending in the region, and ownership linkages of the conglomerates with real sector enterprises within and outside TTO.

\section{Medium-term priorities include the further development of the capital and foreign exchange markets and the deepening of the government securities market. This will improve short-term liquidity management and facilitate a broader and more efficient allocation of resources, especially the increasing energy revenues. Development of financial markets would also help reduce TTO's exposure to currency fluctuations and allow better hedging and financial diversification. Improvements to the informational infrastructure are key to increasing access to finance by small- and medium-sized businesses. In this regard, ongoing improvements to the business credit registry and the recent establishment of an automated credit bureau are very welcome developments.}

Fully aware of these shortcomings, the authorities have begun an ambitious program to strengthen and upgrade the financial system. Key elements of the agenda outlined in the government's 2004 White Paper on the Financial System, ${ }^{1}$ include a far-reaching overhaul of financial sector laws, strengthening of regulation and supervision, implementation of consolidated cross-border supervision of financial conglomerates, bringing less regulated and supervised institutions under closer supervision, enhancing disclosure requirements, and developing market infrastructure.

The challenges are huge, particularly in light of the available skills and resources. The continued strengthening and development of the financial system will require commitment, careful planning and resourcing. Box 1 lists the most important proposed actions. Clearly, many of the recommendations overlap with the measures proposed in the White Paper, and some are already under implementation (Appendix I). The authorities are giving urgent consideration to the needs of staff augmentation, training, and judicious outsourcing. They have already approached the Fund and the Bank for technical assistance to support ongoing efforts.

\footnotetext{
${ }^{1}$ The government adopted in 2004, a White Paper on the Financial System, which has also been tabled in the parliament. It represents the authorities' detailed assessment of the current state of the legislative framework, regulatory architecture, and supervisory practices relating to the financial sector. It elaborates on changes required thereto and a time frame of implementation, for the full realization of the country's goal to become a pan-Caribbean financial center and a high-income economy by the year 2020 .
} 


\begin{tabular}{|c|c|c|}
\hline \multicolumn{3}{|l|}{ Box 1. Key Recommendations ${ }^{2}$} \\
\hline & \multicolumn{2}{|c|}{ TIME FRAME } \\
\hline & Immediate & Medium-term \\
\hline \multicolumn{3}{|l|}{ I. Cross-Sectoral Issues } \\
\hline $\begin{array}{l}\text { Legal issues } \\
\text { - Enact amendments to the FIA, IA, and SIA with a minimum of further delay. } \\
\text { - Consider an insolvency law that incorporates a procedure for the } \\
\text { reorganization or administration of insolvent companies. } \\
\text { - Finalize the drafting of new credit union legislation. }\end{array}$ & $\mathrm{X}$ & $\mathrm{X}$ \\
\hline $\begin{array}{l}\text { Regulatory and supervisory issues } \\
\text { - Ensure that as part of FIA amendments, regulatory requirements: } \\
\text { (i) necessitate CBTT pre-approval of major acquisitions of banks, insurers, } \\
\text { and other financial companies within regulated groups; (ii) establish } \\
\text { home-host responsibilities for regionally active groups consistent with Basel } \\
\text { Core Principles; (iii) introduce consolidated supervision for financial groups } \\
\text { on the basis of supervisable structures; (iv) ring-fence financial from } \\
\text { nonfinancial activities; (v) require licensees to inform authorities of breaches } \\
\text { of legislation; and (vi) introduce capital adequacy requirements at a } \\
\text { consolidated level. } \\
\text { - } \\
\text { Enforce existing regulations on connected exposures. } \\
\text { Accelerate the recruitment of supervisory resources with the appropriate skill } \\
\text { sets. }\end{array}$ & $\begin{array}{l}X \\
X\end{array}$ & \\
\hline $\begin{array}{l}\text { Financial stability framework } \\
\text { - Improve supervisory reporting and databases for better monitoring } \\
\text { cross-sector and cross-border risks, and develop CBTT databases for stress } \\
\text { testing of market and credit risk, including the development of indices on } \\
\text { property prices and consumer lending. } \\
\text { Clarify (i) terms and conditions for access to emergency lending facilities, } \\
\text { distinguishing these from arrangements for handling insolvency, and } \\
\text { (ii) procedures for exit of problem institutions. }\end{array}$ & $\mathrm{X}$ & $\mathrm{X}$ \\
\hline \multicolumn{3}{|l|}{ II. Sectoral Issues } \\
\hline $\begin{array}{l}\text { Banking } \\
\text { - Increase risk weight on lower investment grade and non-OECD sovereign } \\
\text { exposure. }\end{array}$ & $X$ & \\
\hline
\end{tabular}

\footnotetext{
2 The mission also provided a Detailed FSAP Matrix of Recommendations suggesting a broad order of prioritization within each area. Where differences in coverage and emphasis exist, specific details have been provided on corresponding modifications to the White Paper reform agenda. The authorities have further developed the Matrix, integrated it within the White Paper priorities, and identified areas where technical assistance is needed.
} 


\section{Insurance and pensions}

- Introduce risk-based capital requirements and a principles-based investment regime for insurance companies and pension funds.

- Formulate a stronger regime for related lending and investments and rules for investment by insurers in subsidiaries.

- Establish a regulatory framework that deals with the risk inherent in deferred annuity products such as options and asset-liability management.

- Set up guidelines to address conflicts of interest in pension fund management and new regulations to address indexation of pension entitlements.

Securities markets

- Strengthen disclosure requirements, market conduct rules, and mutual fund supervision

- Start on-site inspections and risk based supervision of market intermediaries.

- Review the TTSEC governance structure and resource needs.

Market efficiency and infrastructure

- Promote development of an interbank foreign exchange market and secondary market in government securities.

- Accelerate legal framework updating and clarify participation and contingency arrangements for all stakeholders.

Accounting and auditing practices

- Require external auditors to report material concerns to boards of institutions, CBTT, and the SEC.

- Improve disclosure on valuation methods for illiquid or unquoted securities.

- Insurance groups should adopt consistent, internationally recognized practices in their accounting for annuities, provisioning, and asset valuation.

Access to financial services

- Separate regulation of credit unions from that of other nonfinancial cooperatives; specify their appropriate activities, establish prudential norms and appropriate supervisory oversight.

- $\quad$ Enact Consumer Credit Reporting Bill and Personal Property Protection Bill; encourage the expansion of the credit bureau to cover commercial credit.

\section{Macroeconomic Developments, Financial Structure, And Regulatory CONTEXT}

\section{A. Macroeconomic Developments}

\section{The macroeconomic setting appears stable and poses only moderate immediate} risks to financial stability. TTO is benefiting from high energy prices as reflected in fiscal surpluses and accumulation of foreign exchange reserves (Box 2). The energy sector, including oil and gas, which accounts for over 40 percent of GDP, and makes up over 80 percent of export revenues has been growing at an annual average of 18 percent since 2002, owing to favorable price movements and strong investments in natural gas facilities. Energy export earnings have translated into large current account surpluses, averaging over 7 percent of GDP over the past three years. With the rise in the government's energy revenues, a sizeable central government fiscal surplus has emerged. The larger external inflows resulting from higher oil prices have led to a substantial buildup of foreign exchange reserves, reductions in government debt, and capital outflows to the CARICOM 
and other countries. At the same time, however, expenditures have picked up, resulting in a marked widening of the government's nonenergy deficit.

\section{Box 2: Trinidad and Tobago: Regional Comparisons}

Compared with countries in the region, TTO has enjoyed the strongest growth performance and fiscal stance. During the last five years, the fiscal deficit averaged 2 percent of GDP — significantly lower than in Belize, Jamaica, and the ECCU countries. At end-2003, total public debt stood at around 60 percent of GDP, compared with an average of 80 percent of GDP for the ECCU. TTO has the highest current account surplus and international reserves coverage in the Caribbean region. Reflecting its low public debt ratio and strong economy, TTO (A-) — along with Barbados (A-) — are the only two Caribbean countries with investment-grade sovereign ratings. TTO dollar interest rates are generally at or below the median for the Caribbean, with treasury bill rates in the range of 4-5 percent and domestic interest rate spreads about 8-9 percent. TTO's per capita income is close to US\$8,000.

\begin{tabular}{|c|c|c|c|c|c|c|}
\hline & $\begin{array}{l}\text { Real GDP } \\
\text { Growth } \\
2003 \\
\text { in percent }\end{array}$ & $\begin{array}{l}\text { Nominal } \\
\text { GDP } \\
2003 \\
\text { in billions } \\
\text { of USD }\end{array}$ & $\begin{array}{c}\text { GDP per } \\
\text { Capita } \\
2003 \\
\text { in thousands } \\
\text { of USD }\end{array}$ & $\begin{array}{l}\text { Fiscal } \\
\text { Balance } \\
\text { percent } \\
\text { of GDP }\end{array}$ & $\begin{array}{c}\text { Public Debt } \\
2003 \\
\text { percent } \\
\text { of GDP }\end{array}$ & $\begin{array}{c}\text { Sovereign } \\
\text { Rating } \\
\text { S\&P }\end{array}$ \\
\hline Antigua and Barbuda & -1.0 & 0.8 & 11.1 & -7.9 & 114 & $\ldots$ \\
\hline Barbados & 1.2 & 2.7 & 9.7 & -5.0 & 84 & A- \\
\hline Belize & 7.2 & 1.0 & 3.9 & -10.9 & 93 & B \\
\hline Dominican Republic & 5.2 & 16.3 & 1.8 & -3.2 & 56 & $\mathrm{BB}$ \\
\hline Dominica & -0.5 & 0.3 & 3.6 & -8.2 & 122 & $\ldots$ \\
\hline Grenada & 3.3 & 0.4 & 4.1 & -7.1 & 109 & SD \\
\hline Guyana & 0.2 & 0.7 & 0.9 & -5.9 & 179 & $\ldots$ \\
\hline Haiti & 0.8 & 3.9 & 0.5 & -3.8 & 44 & $\ldots$ \\
\hline Jamaica & 0.9 & 7.9 & 3.0 & -8.5 & 142 & BB- \\
\hline St. Kitts and Nevis & 2.7 & 0.4 & 7.6 & -11.2 & 160 & $\ldots$ \\
\hline St. Lucia & 0.7 & 0.7 & 4.0 & -2.5 & 66 & $\ldots$ \\
\hline $\begin{array}{l}\text { St. Vincent and the } \\
\text { Grenadines }\end{array}$ & 2.3 & 0.4 & 3.3 & -3.5 & 71 & $\ldots$ \\
\hline Suriname & 2.5 & 1.2 & 2.5 & -6.3 & 44 & $\ldots$ \\
\hline Trinidad and Tobago & 13.3 & 10.8 & 8.3 & 2.0 & 55 & A- \\
\hline
\end{tabular}

\section{B. Financial System Structure}

2. The TTO financial system is large and complex. By total assets relative to GDP (170 percent), the financial sector is large relative to countries at comparable income levels. The last decade has seen remarkable growth and structural change in the financial system. Growth of the banking sector has been outpaced by nonbanks, particularly the contractual savings sector, ${ }^{3}$ which now accounts for a majority of assets (Figure 1, Table 1). Major

\footnotetext{
${ }^{3}$ The contractual savings sector includes insurance and pension funds, mutual funds, and the Unit Trust Corporation of Trinidad and Tobago (UTC).
} 
segments of the financial system exhibit oligopolistic concentration: the two largest commercial banks account for up to 60 percent of all assets, while the two largest insurers account for 85 percent of all new business written and 87 percent of the income of the life insurance business.

Figure 1. Trinidad and Tobago: Financial System Structure
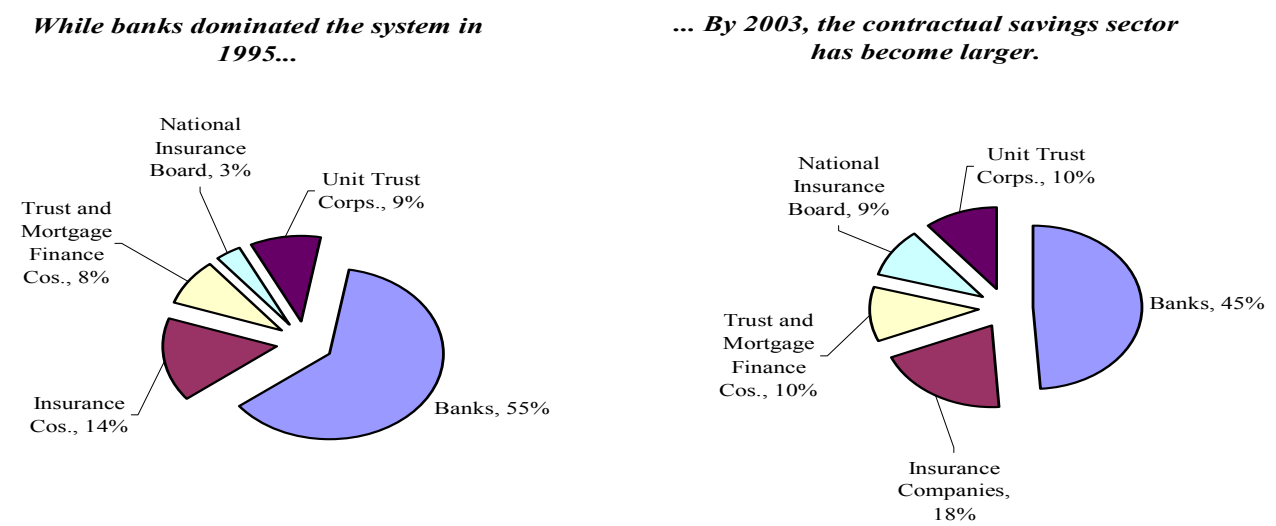

Banking sector is heavily concentrated
(as measured by asset ownership) ....

... as is the insurance industry.
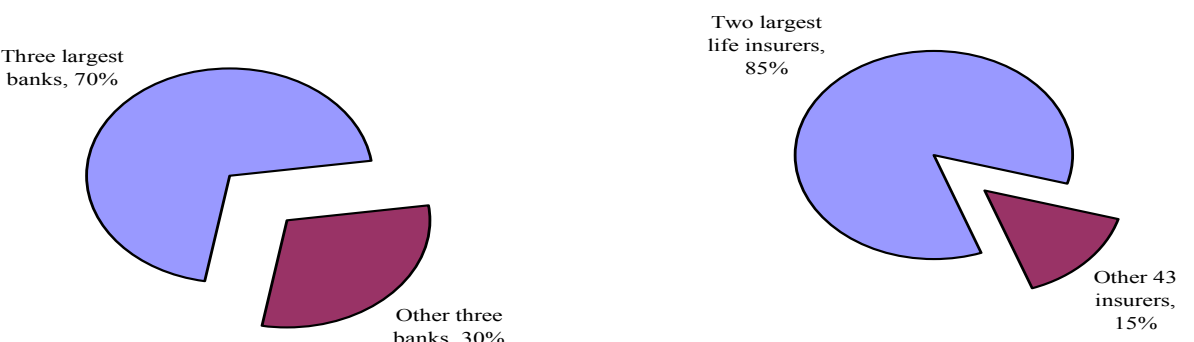

Note: The banking sector includes all institutions licensed under the Financial Instutions Act (FIA): commercial banks, merchant banks, finance companies, and trust companies. 
Table 1. Trinidad and Tobago: Asset Composition by Type of Institution (in percentage points)

\begin{tabular}{lrrrrrr}
\hline Type of Institution & 1995 & 1999 & 2000 & 2001 & 2002 & 2003 \\
\hline Commercial Banks & 50 & 43 & 44 & 44 & 42 & 38 \\
Insurance Companies & 14 & 17 & 15 & 16 & 17 & 18 \\
Finance Companies and Merchant Banks & 5 & 8 & 6 & 7 & 7 & 7 \\
Trust and Mortgage Finance Companies & 9 & 11 & 12 & 10 & 10 & 10 \\
Occupational pension funds 1/ & & & & $(16)$ & $(16)$ & $(16)$ \\
$\quad$ Mutual Funds 1/ & & & & $(11)$ & $(15)$ & $(18)$ \\
National Insurance Board & 8 & 8 & 9 & 8 & 9 & 9 \\
Unit Trust Corporation & 3 & 5 & 6 & 6 & 9 & 10 \\
Credit Unions & 6 & 5 & 4 & 4 & 4 & 5 \\
Development Banks & 2 & 2 & 2 & 2 & 1 & 2 \\
Thrift Institutions & 0 & 0 & 0 & 0 & 0 & 0 \\
Home Mortgage Bank & 2 & 1 & 1 & 1 & 1 & 1 \\
Stock Exchanges & 0 & 0 & 0 & 0 & 0 & 0 \\
Deposit Insurance Corporation & 0 & 1 & 1 & 1 & 1 & 1 \\
Total & 100 & 100 & 100 & 100 & 100 & 100 \\
\hline
\end{tabular}

Sources: Trinidad and Tobago, White Paper on the Financial System, 2004; Quarterly Statistical Digest of the CBTT, June 2004; Annual Reports of the TTO Home Mortgage Bank, Unit Trust Corporation, and Stock Exchange.

$1 /$ Occupational pension fund and mutual fund assets are important components. However, since a large proportion of these funds are managed by insurance or trust companies, their assets have not been added to the system total so as to avoid double counting.

Table 2. Trinidad and Tobago: Share of Conglomerates in the Financial System

(In Trinidad and Tobago dollars, unless otherwise specified)

\begin{tabular}{|c|c|c|c|c|c|}
\hline \multicolumn{2}{|c|}{ Licensed Financial Institutions 1/ } & \multicolumn{4}{|c|}{ Life Insurance } \\
\hline & Amount & $\begin{array}{l}\text { Share } \\
\text { (in } \\
\text { percent) }\end{array}$ & & Amount & $\begin{array}{l}\text { Share } \\
\text { (in } \\
\text { percent) }\end{array}$ \\
\hline System assets (2004) & 67,518 & 100 & In-force business 2/ (2003) & 29,395 & 100 \\
\hline Domestic & 42,341 & 64 & Domestic & 17,740 & 60 \\
\hline $\begin{array}{l}\text { Foreign-owned or foreign- } \\
\text { affiliated }\end{array}$ & 10,779 & 16 & $\begin{array}{l}\text { Foreign-owned or foreign- } \\
\text { affiliated }\end{array}$ & 6,843 & 24 \\
\hline
\end{tabular}

Source: CBTT.

1/ Includes commercial banks; finance companies and merchant banks; and trust and mortgage finance companies. Data are for Trinidad and Tobago-based companies within the major groups.

2/ As a proxy for total assets.

3. A small number of conglomerates dominate the financial system (Figures $2 \mathrm{a}$ and $2 \mathrm{~b}$, Table 2). Two are regionally active banking and securities group; a third is a mixed activities group that engages in both financial and nonfinancial operations; another is primarily a nonfinancial entity, which developed banking and securities largely as ancillary 
operations. Locally incorporated subsidiaries of certain large foreign-owned financial conglomerates are also active in TTO, particularly in the insurance area. Over time, the ownership structures of - and the financial and ownership linkages among — these groups have also evolved in different ways, with some having a publicly-held and widely dispersed ownership base and others being family-owned businesses.

Figure 2a. Conglomerates' Share in the Assets of Licensed Financial Institutions, 2003 (In percent)

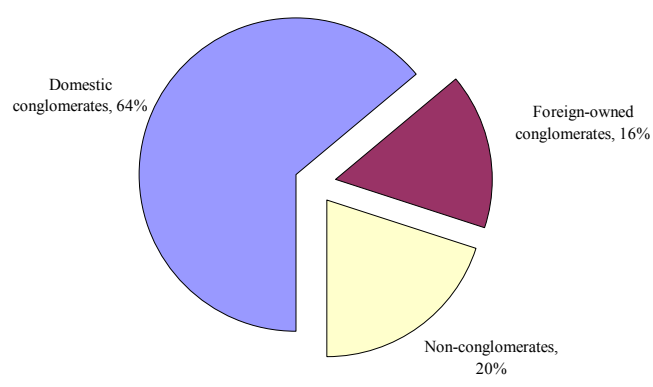

Figure 2b. Conglomerates' Share in the Life Insurance Business, 2003 (In percent)

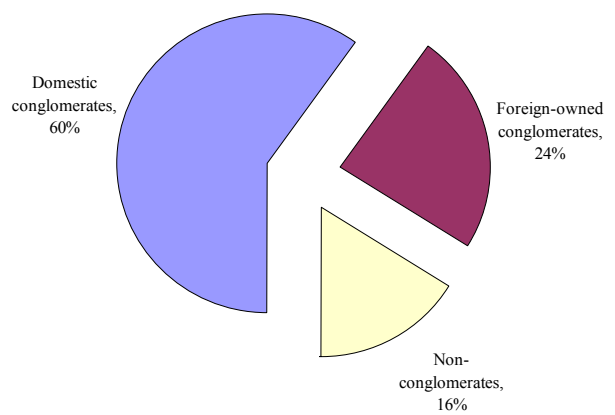

\section{Regional linkages}

4. Cross-border integration of the TTO financial system is taking place rapidly. As of December 2004, the banking system's loans and investments abroad were spread over 20 countries and a single local insurance company conducted business in over 22 countries. The conglomerates have acquired an array of financial and nonfinancial subsidiaries throughout the Caribbean and operate as prominent lenders, direct investors, underwriters of regional securities, and asset managers.

\section{A large proportion of the external lending and investment of TTO's financial} sector is concentrated within the region (Table 3). CARICOM countries account for 85 percent of TTO banks' loans and investments abroad. Direct exposure of commercial banks to the region is low relative to capital, but exposure of investment banks is substantially larger, thereby increasing overall exposure at the conglomerate level. Inclusion of the regional investments of insurance companies, pension funds and mutual funds would raise this exposure still further.

\section{Regional integration has also progressed through the securities markets.}

Since 1997, around 18 percent of new equity issues on the Trinidad and Tobago Stock Exchange (TTSE) have been accounted for by cross-listings of CARICOM companies. Growth of regional investments through collective investment schemes has been rapid. By the end of 2003, around 30 percent of unit trusts in the TTO market were registered by local agents representing foreign issuers. Regional bond issuers have been slower to gain market share, with foreign bonds accounting for 13 percent of all bond issues in the year to September 2004. 
Table 3. Trinidad and Tobago: Geographic Exposure of Financial System Assets ${ }^{1}$

(As of December 2004, in percentage points)

\begin{tabular}{llc}
\hline & Country & Percent \\
\hline Domestic & & 76.1 \\
Caribbean & & 20.4 \\
of which: & Barbados & 3.6 \\
& Dominican Republic & 1.1 \\
& Grenada & 1.1 \\
& Jamaica & 3.9 \\
& St. Lucia & 5.8 \\
& St. Maarten & 1.3 \\
Rest of Western Hemisphere & & 3.1 \\
of which & United States & 2.4 \\
\hline
\end{tabular}

Source: CBTT.

1/ Geographical allocation of the equity, loans and investment portfolio of: commercial, merchant, and investment banks; finance companies; and trusts licensed by the CBTT. For St. Lucia, it is important to note that about half of this figure represents investment through a special purpose vehicle, although the mission was unable to secure detailed information.

\section{Financial Regulation and Supervision}

7. TTO is in the process of upgrading its regulatory and supervisory framework to facilitate better assessment of risks at a consolidated level. Recent experience in the insurance industry suggests that balance-sheet mismatches arising from innovative funding strategies or cross products are difficult to recognize quickly under the current sector-based supervisory approach. This underscores the desirability of carrying out supervision of individual institutions based on the risk carried on- and off-balance sheets, and in the products, they offer. Recent developments also point to the need for strengthening the legal framework to empower relevant supervisory agencies to limit, and when necessary, to prohibit activities that may result in balance-sheet mismatches. This process has been given impetus through the transfer of insurance and pension supervision to the CBTT in 2004.

\section{Regulation of other nonbank institutions remains fragmented and is in the} process of being streamlined and strengthened. ${ }^{4}$ Mutual fund supervision is inadequate, largely owing to deficiencies in the governing legislation. The draft Securities Industries Act (SIA), if enacted, will provide for comprehensive TTSEC supervision of all mutual funds. The TTSEC has also regulatory supervision of the bond market. The TTSEC regulates the conduct of all market participants in the capital markets as well as monitoring activities in the

\footnotetext{
${ }^{4}$ The National Insurance Board (NIB) oversees the public pension system, while the Securities Exchange Commission (TTSEC) and the CBTT share in the supervision of mutual funds and the securities industry, with the CBTT having responsibility for funds operated by the banks while the primary jurisdiction for the regulation of mutual funds as securities lies with the TTSEC. Moreover, the UTC falls under the regulatory jurisdiction of the TTSEC.
} 
primary and secondary markets. The TTSE plays a self-regulatory role over members of the stock exchange, as does the T\&T Central Depository over its members. Credit unions are supervised by the Minister of Labor and the Minister of Finance and governed by the outmoded Cooperative Societies Act, but such oversight is largely for purposes of administration and organizational matters and not for monitoring financial performance. ${ }^{5}$

\section{ISSUES IN FINANCIAL SYSTEM STABILITY}

\section{A. Short-Term Stability Issues}

\section{Macroprudential analysis and stress testing}

9. The banking sector is well capitalized and provisioned (Table A1). The current system average capital adequacy ratio of 21 percent is well in excess of the minimum 10 percent regulatory requirement. Loans to the private sector constitute over 40 percent of total banking assets, with consumer lending being the single largest item (Table 4). Interbank lending is negligible. Deposit dollarization, at 35 percent is high, but apparently stable, and most banks' net open positions are within the 10 percent-of-capital ceiling. Foreign exchange lending by banks to unhedged domestic borrowers does not - given available evidenceappear to be a major risk factor.

Table 4. Trinidad and Tobago: Commercial Bank Loans by Sector (In percentage points)

\begin{tabular}{lccc}
\hline Sector & 2002 & 2003 & 2004 \\
\hline Government & 7.4 & 6.0 & 8.9 \\
State-owned financial institutions & 0.2 & 0.2 & 0.8 \\
Inter-bank & 0.5 & 1.8 & 0.3 \\
Private financial & 1.1 & 5.2 & 1.6 \\
Private nonfinancial & 48.5 & 48.3 & 49.0 \\
$\quad$ of which: & & & \\
$\quad$ Manufacturing & & 10.3 & 8.6 \\
$\quad$ Agriculture & & 0.6 & 0.5 \\
$\quad$ Trade and Entertainment & 7.3 & 5.6 \\
$\quad$ Real Estate and Mortgage & & 2.0 & 6.2 \\
Consumer & 42.3 & 38.6 & 39.4 \\
Total & 100.0 & 100.0 & 100.0 \\
\hline
\end{tabular}

Source: CBTT.

10. The rapid recent increase in stock market capitalization is largely explained by a rapid increase in share prices. Stock market capitalization, as a percentage of GDP, grew

\footnotetext{
${ }^{5}$ As per a decision taken by the government after the FSAP in July 2005, credit union supervision, which is currently the responsibility of the Division for Cooperative Development in the Department of Labor and Cooperatives, will be transferred to the CBTT.
} 
from 13 percent in 1994 to 144 percent in 2004 (Figure 3), an especially striking development given that over the same period, the ratio of private sector credit-to-GDP remained flat at 40 percent. While a comprehensive analysis of this trend is constrained by data, price series of 13 major listed firms for the period 1999-2004 reveal an unweighted, average five-year increase of 160 percent. Moreover, share prices of firms in the financial and manufacturing sectors have increased far more rapidly than their earnings. (Figure 4).

Figure 3. Trinidad and Tobago: Credit and Equities Markets

(As a percentage of GDP)

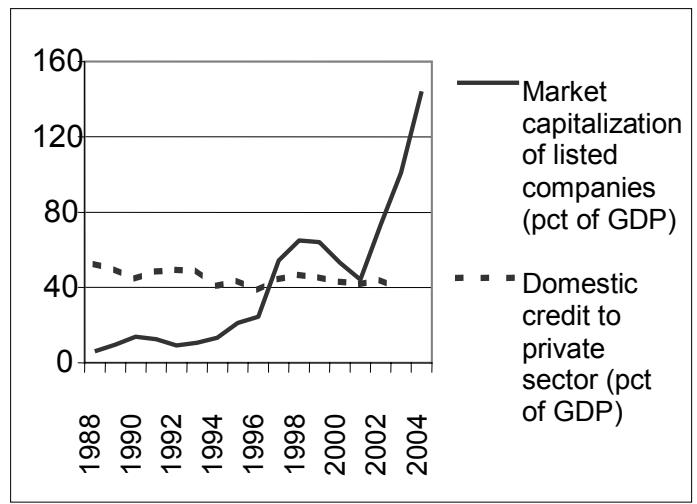

Source: World Development Indicators, 2005.
Figure 4. Trinidad and Tobago: Monthly Price and Earnings Data for the TTSE (By sector)

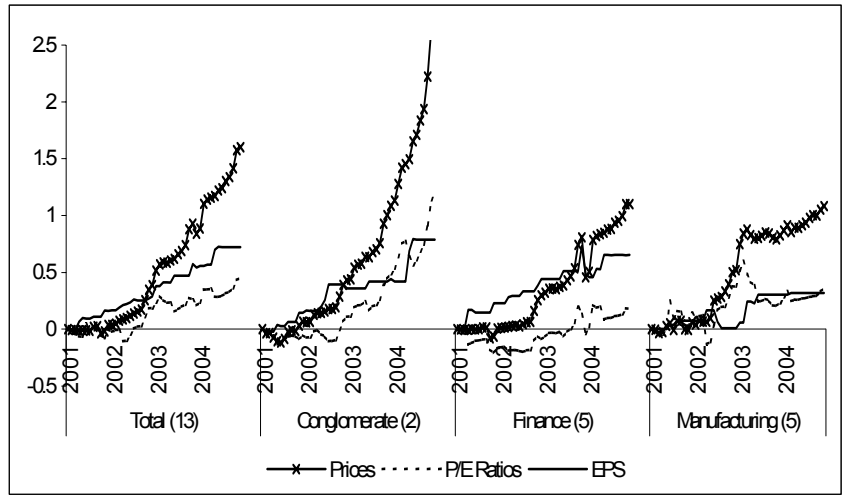

Source: EMDB. All data is indexed to zero at January 2001.

11. High levels of connected exposures across banking and insurance companies considerably increase the risk of contagion. These cross holdings mask the underlying low level of equity supporting both businesses within some conglomerates. A majority of the assets of certain intermediaries are in the form of connected exposures leaving the parent groups vulnerable. Moreover, liquidity problems at these conglomerates could have systemic implications for the payments system and for domestic asset prices.

12. The main threat to macroeconomic and financial stability is the potential impact of a large, sustained decline in energy prices. Lower energy revenues would dampen government spending, energy sector investment, corporate sector profitability and private incomes. Property and equity prices would also likely be adversely affected, harming asset and collateral values in the financial sector. Finally, a significant shock to energy prices would put pressure on the exchange rate and could lead to upward pressure on interest rates.

\section{Stress tests indicate that in the near term, the banking system should be able to} withstand a combination of market and credit quality shocks associated with a substantial decline in energy prices. ${ }^{6}$ In the absence of countervailing action, however, some parts of the banking system could be severely affected, especially those with large lending exposures to domestic industry and property markets. These banks would experience

\footnotetext{
${ }^{6}$ Table 5 provides a summary of the stress tests and main risks to financial stability. Appendix II provides further background on the design of the stress tests.
} 
problems, even though the system as a whole would not be undercapitalized. Credit default is the most significant risk factor compromising banking stability in the event of energy price deterioration. Defaults on bank loans are estimated to account for 90 percent of resulting losses over the short-to medium-term.

14. The equity and property markets may be vulnerable to significant downward price corrections. Since end-2001, average stock prices have risen by from 30 to 40 percent per annum, boosting the average estimated price/earnings ratio to above 20 currently. By emerging market standards these ratios are exceptionally high. Some of the increase can be justified by falling interest rates and strong economic growth, but a significant reversal of recent increases is a risk factor especially in view of the low liquidity in the equities market. Reliable data on the housing market is scarce, precluding a quantitative assessment of risks, but anecdotal evidence and significantly increased mortgage lending suggest that reversal of property price increases is also becoming a risk factor.

\section{A sudden reversal in equity prices will exercise an adverse impact upon the} contractual savings sector. Although profit and liquidity indicators for life insurers currently appear robust (Table A2), up to 40 percent of their assets are in equities. Pension funds have also increased their equity exposure very rapidly in recent years. This suggests that large reductions in profits and asset values can be expected at these institutions from a significant decline in share prices, especially if recent gains were removed from balance sheets through dividends or other distributions.

\section{Increased regional integration of the financial system brings risks as well as}

benefits. The international diversification of the financial system's lending and investments is sensible in so far as the cyclical component of real output in TTO and the rest of the region appears to be negatively correlated. However, there is also important contagion risk associated with the high concentration of exposure in a few counties within the region facing fiscal stress.

\section{Commercial banks' direct exposure to the CARICOM region is low relative to}

capital. ${ }^{7}$ Hence, even very large losses on these exposures, as could be implied by large-scale debt restructuring in the region could pose only moderate threat to the commercial banks' financial condition. Regulatory reclassification of regional government securities to 100 percent risk-weighted would have a similarly negligible impact on banking system CAR.

\footnotetext{
${ }^{7}$ Direct, on-balance sheet exposure to the CARICOM region is equivalent to only 5 percent of commercial banks' capital. It is important to note, however, that indirect exposures are likely to increase the shock impact beyond that reported here. Data limitations have precluded a precise quantitative estimation of the indirect impact through commercial banks' linkages to other parts of the financial system and the wider economy. Commercial banks' cross-shareholdings in other TTO financial institutions, their memberships in regionally active conglomerates, and purchase of any options on regional sovereign and corporate debt, could all increase regional exposure indirectly.
} 
18. Stress tests indicate that the impact of a regional crisis would be felt most sharply by TTO's merchant banks and could have a significant impact on the parent conglomerates. A major decline in the market value of regional assets results in a small reduction in commercial banks' capital, but reduces the capital of merchant banks quite substantially, necessitating in some cases, an injection of capital to return them to solvency. Where these investment banks represent an important component of conglomerates' business operations, the latter's own local capital experiences a sharp reduction.

Table 5. Trinidad and Tobago: Summary of Stress Tests and Main Results

\begin{tabular}{|c|c|c|c|}
\hline & Banks & Insurance Companies & Financial Conglomerates \\
\hline Institutions & $\begin{array}{l}\text { All six banks, } 100 \text { percent of } \\
\text { banking assets. }\end{array}$ & $\begin{array}{l}\text { Life insurance sector, } \\
\text { covering } 87 \text { percent of } \\
\text { gross premiums written } \\
\text { in } 2004 \text {. }\end{array}$ & $\begin{array}{l}\text { Financial groups, with } \\
\text { more than } 50 \text { percent of } \\
\text { financial system assets. }\end{array}$ \\
\hline Exposures & Banking and trading books. & Investment portfolio. & $\begin{array}{l}\text { Banking and trading books, } \\
\text { investment portfolio. }\end{array}$ \\
\hline Risks & $\begin{array}{l}\text { Banking book-market and } \\
\text { credit risk; Trading book- } \\
\text { market risk; Regional } \\
\text { investment exposures. }\end{array}$ & $\begin{array}{l}\text { Market risk on } \\
\text { investment portfolio. }\end{array}$ & $\begin{array}{l}\text { Combination of banking } \\
\text { and insurance risks; } \\
\text { Contagion risk due to } \\
\text { connected lending/ } \\
\text { exposures. }\end{array}$ \\
\hline Horizon & $\begin{array}{l}\text { Market risk - quarterly and } \\
\text { annual; Credit risk-1 to } 2 \\
\text { years. }\end{array}$ & Not Applicable. & Not Applicable. \\
\hline Single-factor shocks & $\begin{array}{l}\text { Interest rate and yield curve, } \\
\text { currency, credit, property } \\
\text { prices, regional asset values. }\end{array}$ & $\begin{array}{l}\text { Interest rate, currency, } \\
\text { property prices, regional } \\
\text { asset values. }\end{array}$ & $\begin{array}{l}\text { Interest rate, currency, } \\
\text { property prices, regional } \\
\text { asset values. }\end{array}$ \\
\hline Scenarios & $\begin{array}{l}\text { Sustained decline in energy } \\
\text { prices; Regional crisis. }\end{array}$ & Regional crisis. & Regional crisis. \\
\hline Main risks identified & Credit, Interest Rate & Equity prices & Regional crisis. \\
\hline
\end{tabular}

\section{Risk management by financial institutions}

19. A major part of the merchant banking activities comprise securitized, structured products based on debt issued by relatively high-risk regional borrowers. Banks are exposed to the legal and reputational risk, even if their own credit and market risk exposure is small. The CBTT will need to consider both strengthening the banks' risk management practices in this area and amending their capital adequacy rules to ensure, for example, that residual retained risks are appropriately identified and treated. Consideration should also be given to harmonizing regional regulatory practice in this regard.

\section{Risk management within the financial sector needs to be strengthened}

considerably. An explicit identification of risks associated with options built into various credit and life insurance products, and the development of appropriate valuation techniques is critical. As trading and securities businesses are becoming more important to domestic banking and insurance groups, they need to develop stress testing approaches for the 
management of market and credit risk. Such techniques are currently being developed by some — but not all — of the internationally active conglomerates.

\section{Sectoral vulnerabilities in the supervisory framework}

\section{Banks and consolidated supervision}

21. The review of compliance with the Basel Core Principles (BCP) indicates that while the supervision of credit risk is generally sound, there remain some areas of concern. ${ }^{8}$ Deviations from internationally accepted practices were identified with regard to: (i) an absence of capital charges on market risk (except for a ten percent charge on foreign currency net open positions); and (ii) lack of compliance by most banks with large and related exposure limits (Table 6).

Table 6. Banking Sector Regulatory Compliance Indicators (Number of banks in violation, unless otherwise specified)

\begin{tabular}{lc}
\hline & 2004 \\
\hline $\begin{array}{l}\text { Single customer exposure to capital } \\
\text { Exposure on unsecured loans }>5 \text { percent }\end{array}$ & 5 \\
Exposure on secured loans $>25$ percent & 4 \\
Aggregate related-party exposures to capital & \\
$\quad$ Exposure $>20$ percent & 4 \\
Net open position to capital & \\
Exposure $>10$ percent & 2 \\
Memorandum Item: & \\
Number of banks & 6 \\
\hline
\end{tabular}
Source: CBTT.

22. There are some additional areas in which banking supervision could be strengthened. These include reducing the "controlling shareholder" threshold and related lending limits; strengthening pre-approval, pre-notification requirements for changes in significant shareholdings; raising risk weighting for non-OECD sovereign debt exposures to Basel norms; broadening coverage of capital charges for market risks; and strengthening CBTT's remediation and enforcement powers.

23. The nature of activities of the conglomerates raise a number of issues that need careful consideration to ensure the effectiveness and consistency of the planned consolidated supervision framework (Box 3). Consolidated supervision of conglomerates that combine insurance with banking and securities activities is problematic given differences in accounting and minimum capital/solvency standards. In other jurisdictions, a group's insurance activities are typically separated from banking and securities by deduction of the

\footnotetext{
${ }^{8}$ See Annex on TTO's compliance with the BCP.
} 
capital concerned and then considered separately. TTO's life insurers, unlike banks, do not currently incur risk-based capital charges for noninsurance risks but are instead subject to restrictions on the deployment of assets held in statutory funds. General insurers are subject to margin of solvency rules.

Box 3. Challenges in Consolidated Supervision

With the prospective adoption of consolidated supervision of internationally active financial conglomerates, the authorities will face the following important challenges:

- Ensuring that all groups are organized on a supervisable basis ${ }^{9}$ may require restructuring some groups to ring-fence regulated financial entities from nonfinancial entities;

- Adopting a minimum risk-based capital regime for groups that is appropriate for those that include both insurance and banking entities. Consistency in the treatment of life insurance business is particularly problematic as there is less of an international consensus on appropriate standards than is the case in banking;

- Addressing the issue of intra-group and group-wide exposures. More effective monitoring and implementation of existing rules would contribute significantly to mitigating risks to the system. New regulations/policies are needed for mixed groups wanting to centralize treasury and other risk management operations on efficiency grounds. A strategy will also need to be agreed with the firms concerned to reduce existing intra-group exposures where these fall outside the guidelines;

- Establishing agreements with other regulators covering respective home-host responsibilities in respect of each group and the exchange of confidential supervisory information. It will also be important for the CBTT to exercise powers to limit or prohibit expansion in countries where the flow of supervisory information is impeded;

- Implementing the CBTT's intention to apply the same group- and risk-based approach to insurance business. The challenges are greater in the life insurance area given the absence of a clear choice of international model appropriate for local conditions and the complexity of local group structures. More comprehensive information on cross-border investments held by statutory funds will be needed. Moreover, existing investment rules affecting the geographical and sectoral allocation of assets are not risk-based. There is no consolidated supervision of insurance entities under a common ownership nor are there powers to exchange information with other regulators. Progress in these areas is a priority even in advance of the passage of amendments to the FIA and the IA.

24. Steps are under way to address weaknesses in all these areas. Recently, the CBTT has supplemented minimum legal requirements by promulgating "prudent person" guidelines for investment and lending that are to be applied to all regulated institutions. While falling short of a comprehensive risk-based capital regime, these guidelines should help to bring greater consistency to conglomerates' internal policies concerning risk tolerances and capital allocation. Proposed amendments to the FIA are in an advanced stage and if adopted, these will generally tighten exposure limits and lower thresholds for supervisory review.

\section{Insurance and pensions}

\section{Supervision of insurance companies is in a start-up phase following the transfer of supervisory oversight to CBTT in 2004. Supervisory practices are improving, and the}

\footnotetext{
${ }^{9}$ A supervisable institution refers to one that is legally bound to provide information (both on a regular basis and on demand) to the corresponding supervisory agency without having to rely on suasion or good will.
} 
proposed revisions to the FIA and the Insurance Act (IA) will introduce greater consistency in the regulation of these institutions and banks. Work is also under way to revise the IA to bring it into line with international practices and the IAIS Insurance Core Principles. Since it is likely to take some time to adopt and implement the legislation, the CBTT has sensibly begun focusing on strict enforcement of existing rules and supervisory requirements.

\section{The main priority for strengthening supervision and regulation of insurance} companies and pension funds is to revise the IA and to pass a revamped Pensions Act (PA). A revised IA needs to give the CBTT authority to regulate and supervise insurance companies as parts of a conglomerate group as well as on a solo basis. The new PA should bring together provisions of the IA relating to pensions, as well as relevant Inland Revenue rules. The new legislation should cover all aspects of benefits legislation and provide for centralized licensing of pension plans.

27. Several areas of risk management and regulation require attention. These include: (i) restrictions on the portfolio composition of insurance company investments that make it difficult for insurers and pension funds to obtain sufficient high quality, readily liquefiable assets; (ii) significant weaknesses in capital standards for both life and motor vehicle insurance; and (iii) potentially inadequate retention limits on property insurance and the need to limit single exposures.

\section{Securities markets}

28. The current framework for securities market regulation is inadequate. There are major gaps in the SIA, including in the areas of mutual funds, governance, and enforcement powers. Importantly, the Act does not provide the TTSEC with the power to conduct on-site supervision of market participants or sufficient powers for regulating the TTSE as a self-regulatory organization. The passage of the revised SIA aimed at strengthening the regulatory framework is, therefore, a matter of priority. The draft legislation could also benefit from further review in the area of risk-based regulation, protection for whistleblowers, and the governance and independence of the TTSEC.

\section{TTSEC regulatory jurisdiction over the Unit Trust Corporation (UTC) should}

be clarified. Given the dominance of the UTC in the mutual funds market, it should be made clear that the powers granted to the UTC under its statute are indeed subject to the jurisdiction of the SIA and the TTSEC. There are other areas of regulatory imbalance with respect to the UTC - e.g., its enjoyment of tax advantages - that may need to be addressed. While the new securities bill, when passed, will formally bring all mutual funds under TTSEC regulation, there is a case for immediately increasing the quality of supervision of all mutual funds particularly, in respect of disclosure and continuous reporting before the new legislation is passed.

\section{The TTSEC needs to build confidence in the securities markets and in its} effectiveness as a regulator. Concerns regarding unfair trading practices and low levels of investor education partly reflect inadequacies in the current SIA, but also the difficulty that TTSEC has had in establishing itself as a modern securities regulator with current resources. 
A review of staffing requirements and funding arrangements needs to be conducted as a matter of priority.

\section{Credit Unions}

31. There is a need to clearly define the nature and business of credit unions and to comprehensively review their regulation and supervision. The activities of credit unions have gone well beyond their traditional bounds, and are currently virtually unregulated. The decision after the FSAP to bring credit unions under the supervision of the CBTT is a clear recognition of the need to substantially strength the framework within which they operate.

\section{B. Medium-Term Stability Issues}

\section{Liquidity and monetary management}

32. The CBTT has successfully moved toward a market-based approach to liquidity management. In 2002, it introduced an overnight repo rate for short-term treasury bills and notes as its key policy rate. The short-term money market is self-regulated and appears to work well, and turnover in the interbank market has been increasing. Since 2003, CBTT has also cut reserve requirements for commercial banks from 18 percent to 11 percent, and the intention is to reduce them further to 9 percent, consistent with the requirement for other licensed financial institutions.

33. The authorities have indicated their desire to introduce greater flexibility into the exchange rate system. Officially, the exchange rate regime is a managed float, but in practice operates as a stable peg vis-à-vis the U.S. dollar. The authorities recognize that even a limited degree of flexibility would encourage development of a true foreign exchange market, with the important benefits of obliging financial market participants to take currency risk into account, and permitting development of market instruments to manage and hedge such risk.

34. Development of the foreign exchange market could be encouraged by reducing illiquidity and uncertainty of supply. ${ }^{10}$ Despite the large current account surplus, banks and foreign exchange dealers tend to face shortages of foreign exchange, reflecting the fact that the government's energy-related foreign exchange revenues (accounting for around 30 percent of all foreign exchange earnings) are deposited directly with the CBTT. As a result, the currency tends to face downward pressure, which is relieved by periodic sales of foreign exchange by CBTT to foreign exchange dealers. The CBTT could facilitate market development by introducing more frequent and regular sales of foreign exchange to market participants to increase the predictability of a continuous supply of foreign exchange. The CBTT could also consider introducing foreign exchange auctions to allow market forces

\footnotetext{
${ }^{10}$ Currently there is no real market for foreign exchange - trading is between FX dealers and retail clients. A nonmarket sharing arrangement is also used to distribute among dealers the repatriated earnings of three large government owned energy sector companies.
} 
more scope to determine the exchange rate. Auctions could facilitate and complement measures to develop an interbank foreign exchange market. These steps, however, would need to be carefully coordinated with market participants.

\section{In recent years, fiscal restraint has led to a rapid build up in CBTT foreign} exchange reserves equivalent to over 15 percent of GDP. The recent establishment of the Heritage and Stabilization Fund (HSF), to manage the investment of energy revenues is a welcome development, as it will put the disposition of these revenues into a transparent long-term investment framework. ${ }^{11}$ The proposed use of part of this fund for domestic investments is a concern, however, partly because it would tend to reduce the insulation of the domestic economy from energy sector revenues, and partly because it would add to the already high demand for good quality domestic financial assets by institutional investors.

\section{Safety net and contingency planning}

36. The foundations for an effective safety net of licensed institutions appear to be in place but some features merit reevaluation. While deposit insurance is compulsory for licensed financial institutions, ${ }^{12}$ with limits on individual depositor coverage, and with funding split between the institutions and CBTT, the systemic importance of many of these institutions raises the risk of blanket guarantees provided in practice. Moreover, although the CBTT has devoted considerable attention to the resolution of banks that fail to meet prudential requirements, its exit policy needs review and clarification, particularly with regard to the closure of insolvent institutions. Steps need to be taken for the development of a policyholder protection scheme (PPS) in the insurance sector. In addition to directly assisting in the protection of policyholders from undue loss in the event of insolvency, the existence of a PPS has self-regulatory effects on the industry.

37. The framework for managing financial crises and providing emergency liquidity assistance (ELA) needs to be clarified in several areas. A clear and flexible set of guidelines or procedures is likely to be helpful in ensuring that an appropriate decision making framework is established, with clear responsibilities and powers. These include: clearly designating the CBTT facility to be used for ELA; clarifying the terms and conditions for the use of ELA (notably the duration of loans and guidelines for the valuation of different classes of collateral); reviewing the list of institutions eligible for ELA (particularly the eligibility of CBTT-supervised insurance companies, pensions, and credit unions); and providing clearer guidance on when ELA would give way to open bank

\footnotetext{
11 This new institutional arrangement will have implications for the allocation and management of foreign exchange inflows. With the HSF taking over the management of reserves for stabilization purposes, the CBTT may focus its foreign exchange market operations on the area of day-to-day liquidity management.

12 Deposit insurance in TTO is provided through a Deposit Insurance Corporation (DIC) established by the CBTT in 1986.
} 
assistance (OBA) or an infusion of capital from the public sector, and how the management of the problem would be affected.

\section{Financial stability review process}

38. The CBTT's expanded responsibilities relating to financial sector regulation and supervision, and the aspiration of creating a financial center argue for an explicit framework for the maintenance of financial stability. Changing the structure of regulation cannot of itself guarantee effective supervision and financial system stability. A coordinated review process is necessary to ensure a coherent, forward-looking approach to ensuring financial stability. Given the growing complexity of the financial system, the CBTT would need to undertake regular and systematic evaluations of risks and vulnerabilities. Analysis undertaken by the CBTT would not only need to take into account the economic activity and other macroeconomic developments, which significantly affect financial institutions, but also the relevant legal and institutional factors, both within and outside TTO. Particular attention should be devoted to cross-market and cross-sectoral exercises testing for contingency planning and operating mechanisms, in a way that better reflects market innovations and growing institutional complexity in TTO.

39. It is important for the authorities to establish mechanisms for regular information sharing, for synthesizing views on crosscutting issues, and for adapting strategies and policies to maintain financial stability. A high-level group including senior representatives from CBTT, TTSEC, and the Finance Ministry has recently been established to provide strategic guidance on how best to achieve financial stability objectives, both through coordination of activities of relevant parties, and through modifications in responsibilities, resources and methods. The planned Interim Regulatory Council may undertake this role, but its mandate is not yet clear.

\section{MEDIUM-TERM DEVELOPMENT AND STRUCTURAL ISSUES}

\section{A. Access to Financial Services}

40. Developments in the provision of financial services to households and small business have been mixed. Credit unions, which provide financial services to small- and medium-sized enterprises (SMEs) and individuals, including the less well off, have grown rapidly over the last decade, both in membership base and assets. A large part of the recent increase in assets, however, has taken the form of investments rather than lending to members. This suggests that developing a prudential and supervisory framework for credit unions and ensuring good corporate governance is a high priority.

41. The overall provision of financial services to small businesses through other institutional channels continues to be fragmented and largely stagnant, with low returns. Many public and semi-public programs for the provision of SME finance have high levels of liquid assets, limited outreach and, in some cases, high budget outlays relative to the number of clients. A detailed review and streamlining of such programs should be 
undertaken. Risk profiling and quality evaluation of present programs would help to identify and separate the most vulnerable segments of the portfolio. This could then be used to consider prudential limits and performance criteria for public/semi public credit providers.

\section{B. Securities Markets, Insurance, and Pensions}

42. Establishing TTO as a regional financial center will require improvements in equity market transparency and governance, further cross-listings, and additional supply of local listings. The development of electronic trading, and TTSEC standards and surveillance capabilities, should improve market transparency and reduce transaction costs. Privatization of public enterprises could contribute to increasing the supply of local listings.

43. A deeper secondary market for bonds would also support the growth and stability of the financial sector. Primary market activity in fixed interest securities in TTO has been impressive, but secondary market trading has been much less so. Secondary market activity could be stimulated by changing regulations tending to promote buy-and-hold strategies by institutional investors, and by consolidating government-guaranteed debt under a central borrowing authority to maximize their liquidity. The depth of the secondary bond markets could also be assisted by extending the maturity of short-term government securities and exploring the development of an interest rate swap market.

44. Development of the domestic capital market would also benefit the insurance and pension sectors. Increased supply and liquidity in domestic capital markets would facilitate portfolio diversification by insurers and pensions, and make it easier to establish fair market values for securities after issue. Easing limits on investments in overseas assets would also facilitate portfolio diversification and reduce incentives to acquire imprudently large holdings in local companies, including affiliates.

\section{Financial Market Infrastructure}

\section{Payments and settlement systems}

45. The CBTT and other stakeholders have achieved significant results in the reform of the payments system in TTO. ${ }^{13}$ The most important of these was the launch of a Real Time Gross Settlement system (safe-tt), in October 2004, and a custody and settlement system for government securities (GSS), beginning in December 2004. Also planned for 2005 are the creation by the CBTT of a Virtual Private Network to provide the banking community with a secure information network and an Automated Clearinghouse, owned jointly by the CBTT and commercial banks.

46. The legal framework for payments and settlement presents some important weaknesses. The legal basis lacks the elements required for the operation of modern

\footnotetext{
${ }^{13}$ See Annex on TTO’s observance of CPSS Core Principles for Systemically Important Payment Systems.
} 
electronic payments system and full contingency arrangements are pending finalization. The system is operated by the CBTT, which has established a National Payment System Council as a forum of discussion on payment system matters. This should help in the preparation of the required additional regulations.

\section{Financial Integrity}

47. A full assessment of the anti-money laundering and countering the financing of terrorism (AML/CFT) regime in TTO is currently being undertaken by the Caribbean Financial Action Task Force (CFATF). ${ }^{14}$ As regards banks, however, existing legislation and regulations regarding money laundering and terrorism financing have been strengthened by the 2004 revision of the CBTT Guideline on Combating Money Laundering and Terrorist Financing (to take into account the FATF 40 plus 8 recommendations), and a Terrorist Financing Act is currently before Parliament. The regulations and legislation set out detailed requirements for internal procedures and policies of banks, and their external auditors are required to report annually on banks' compliance with the legislation and guidelines. Customer identification records are required to be held for at least six years, and suspicious transactions are required to be reported to the FIU. The AML/CFT guidance issued by the International Association of Insurance Supervisors (IAIS) has been forwarded to the insurance industry for comments and appropriate action.

${ }^{14}$ CFATF originally planned to carry out the assessment simultaneously with the FSAP so that the assessment results could also be reflected in the FSAP. This could not materialize due to logistical limitations faced by the CFATF. 
Table A1.Trinidad and Tobago: Financial Soundness Indicators-Banking Sector, 1999-2005

(In percent, unless indicated otherwise)

\begin{tabular}{|c|c|c|c|c|c|c|c|}
\hline & 1999 & 2000 & 2001 & 2002 & 2003 & 2004 & $20051 /$ \\
\hline \multicolumn{8}{|l|}{ Capital adequacy } \\
\hline Regulatory capital to risk-weighted assets & 17.5 & 20.1 & 19.5 & 20.6 & 20.3 & 22.7 & 21.4 \\
\hline Regulatory Tier I capital to risk-weighted assets & 15.3 & 17.8 & 17.6 & 17.3 & 18.2 & 20.7 & 19.6 \\
\hline Regulatory Tier II capital to risk-weighted assets & 2.2 & 2.3 & 1.9 & 3.3 & 2.2 & 2.0 & 1.9 \\
\hline Regulatory capital to total assets & 10.0 & 11.6 & 11.0 & 11.9 & 11.6 & 13.8 & 12.3 \\
\hline \multicolumn{8}{|l|}{ Banking sector asset composition } \\
\hline \multicolumn{8}{|l|}{ Sectoral distribution of loans to total loans } \\
\hline Households & 48.8 & 45.7 & 42.8 & 41.3 & 40.4 & 39.6 & 40.4 \\
\hline \multicolumn{8}{|l|}{ Of which: } \\
\hline Proportion secured as mortgage loans & 12.0 & 9.8 & 10.2 & 11.4 & 11.3 & 18.3 & 19.9 \\
\hline Financial sector & 20.9 & 23.7 & 21.9 & 22.4 & 28.8 & 28.2 & 26.9 \\
\hline Oil and gas sector & 2.3 & 2.9 & 5.5 & 4.2 & 4.6 & 3.0 & 2.2 \\
\hline Construction sector & 5.2 & 4.5 & 3.8 & 4.6 & 7.4 & 6.5 & 7.2 \\
\hline Communications sector & 5.6 & 6.8 & 4.9 & 3.7 & 3.7 & 3.7 & 3.4 \\
\hline Nonresidents & 2.8 & 1.9 & 2.2 & 3.2 & 2.3 & 4.3 & 4.9 \\
\hline \multicolumn{8}{|l|}{ Geographical distribution of loans to total loans } \\
\hline Domestic & 97.2 & 98.1 & 97.8 & 96.8 & 97.7 & 95.7 & 95.3 \\
\hline Foreign & 2.8 & 1.9 & 2.2 & 3.2 & 2.3 & 4.3 & 4.7 \\
\hline \multicolumn{8}{|l|}{ Of which: } \\
\hline Jamaica & $\ldots$ & $\ldots$ & $\ldots$ & $\ldots$ & $\ldots$ & 7.9 & 11.1 \\
\hline Barbados & $\ldots$ & $\ldots$ & $\ldots$ & $\ldots$ & $\ldots$ & 2.6 & 2.4 \\
\hline Other Caribbean & $\ldots$ & $\ldots$ & $\ldots$ & $\ldots$ & $\ldots$ & 31.3 & 66.0 \\
\hline Large exposures to capital & $\ldots$ & $\ldots$ & $\ldots$ & $\ldots$ & 84.4 & 82.9 & $\ldots$ \\
\hline Gross asset position in derivatives to capital & 0.0 & 0.8 & 6.7 & 5.8 & 8.3 & $\ldots$ & $\ldots$ \\
\hline Gross liability position in derivatives to capital & 0.0 & 0.8 & 1.4 & 1.3 & 4.5 & $\ldots$ & $\ldots$ \\
\hline FX loans to total loans & 22.5 & 24.3 & 30.1 & 31.2 & 17.2 & 25.5 & 25.1 \\
\hline \multicolumn{8}{|l|}{ Banking sector asset quality } \\
\hline NPL to gross total loans & 4.9 & 3.9 & 3.2 & 3.6 & 2.0 & 4.0 & 2.3 \\
\hline NPLs net of provisions to capital & 7.8 & 2.7 & 0.6 & -1.0 & -3.0 & 5.8 & 1.0 \\
\hline Specific provisions to impaired assets & 1.9 & 1.9 & 1.9 & 2.6 & 2.3 & 40.3 & 61.6 \\
\hline Specific provisions to gross lending & 38.2 & 47.3 & 57.7 & 70.8 & 117.5 & 1.6 & 1.4 \\
\hline \multicolumn{8}{|l|}{ Banking sector earnings and profitability } \\
\hline ROA & 1.7 & 1.9 & 2.0 & 2.4 & 2.1 & 3.7 & 3.7 \\
\hline ROE & 17.6 & 17.9 & 17.2 & 20.0 & 16.9 & 27.5 & 27.5 \\
\hline Net interest income to gross income & 36.7 & 37.9 & 36.5 & 43.0 & 47.9 & 38.2 & 38.1 \\
\hline Noninterest expenses to gross income & 40.0 & 39.0 & 39.5 & 43.3 & 50.7 & 41.4 & 41.4 \\
\hline Spread between average lending and deposit rates & 9.5 & 8.8 & 8.4 & 8.7 & 7.1 & 8.5 & 7.3 \\
\hline Net interest income to average earning assets & 5.6 & 5.5 & 5.1 & 5.4 & 5.4 & 4.2 & $\ldots$ \\
\hline \multicolumn{8}{|l|}{ Banking sector liquidity } \\
\hline Liquid assets to total assets & 16.5 & 17.3 & 17.8 & 16.1 & 15.9 & 14.9 & 15.7 \\
\hline Liquid assets to total short-term liabilities & 23.2 & 25.1 & 24.8 & 22.6 & 22.3 & 20.8 & 21.1 \\
\hline Customer deposits to total (noninterbank) loans & 133.6 & 140.2 & 145.3 & 147.2 & 142.3 & 130.6 & 132.5 \\
\hline FX denominated liabilities to total liabilities & 31.2 & 31.1 & 32.6 & 34.3 & 34.4 & 38.4 & 36.7 \\
\hline \multicolumn{8}{|l|}{ Banking sector sensitivity to market risk } \\
\hline Net open positions in FX to capital & 0.1 & -4.0 & -11.8 & -18.2 & -36.8 & -0.9 & \\
\hline
\end{tabular}

Source: CBTT.

1/ Figures for 2005 are for end-March. 
Table A2. Trinidad and Tobago: Financial Soundness Indicators-Insurance Companies, 1999-2004 1/

(In percent, unless indicated otherwise)

\begin{tabular}{|c|c|c|c|c|c|c|}
\hline & 1999 & 2000 & 2001 & 2002 & 2003 & 2004 \\
\hline Growth rate of gross premiums written: Nonlife & - & 17.3 & 4.1 & 28.9 & 9.5 & 3.7 \\
\hline Growth rate of net premiums written: Nonlife & - & 21.9 & 2.4 & 22.5 & 1.7 & 3.9 \\
\hline Growth rate of gross premiums written: Life & - & 25.8 & 30.9 & 10.5 & 67.8 & 16.2 \\
\hline Growth rate of net premiums written: Life & - & 26.9 & 31.6 & 10.8 & 69.5 & 15.9 \\
\hline Growth rate of net premiums earned: Nonlife & - & 22.3 & 2.8 & 17.7 & 5.0 & 3.0 \\
\hline Net premium income to capital/technical reserves: Nonlife & 64.4 & 70.6 & 61.9 & 68.2 & 61.5 & 39.6 \\
\hline Net premium income to capital/technical reserves: Life & 139.9 & 195.0 & 112.9 & 83.6 & 115.7 & 79.5 \\
\hline Net premiums written to total gross premiums: Nonlife & 54.2 & 56.3 & 55.3 & 52.6 & 48.9 & 48.9 \\
\hline Net premiums written to total gross premiums: Life & 95.5 & 96.3 & 96.8 & 97.1 & 98.1 & 97.9 \\
\hline Capital to total assets: Nonlife & 48.9 & 46.6 & 50.6 & 48.1 & 46.8 & 60.2 \\
\hline Capital to total assets: Life & 10.3 & 8.4 & 15.3 & 19.3 & 19.4 & 24.4 \\
\hline Loss ratio: Nonlife & - & 69.9 & 67.3 & 69.6 & 62.8 & 58.7 \\
\hline Loss ratio: Life & 52.7 & 52.6 & 54.8 & 61.6 & 74.2 & 73.8 \\
\hline Expense ratio: Nonlife & 17.8 & 16.7 & 16.7 & 14.7 & 12.6 & 12.5 \\
\hline Expense ratio: Life & 43.5 & 35.8 & 26.1 & 26.9 & 21.4 & 24.0 \\
\hline Combined ratio: Nonlife & - & 86.5 & 84.0 & 84.3 & 75.4 & 71.2 \\
\hline Combined ratio: Life & 96.2 & 88.4 & 80.9 & 88.5 & 95.6 & 97.7 \\
\hline Investment income to investment assets: Nonlife & 8.6 & 9.2 & 6.8 & 8.2 & 11.6 & 7.0 \\
\hline Investment income to investment assets: Life & 8.9 & 11.0 & 13.8 & 9.4 & 11.0 & 9.7 \\
\hline Underwriting profit to net investment income: Nonlife & -20.8 & -23.2 & -19.7 & -19.4 & 22.7 & 36.2 \\
\hline Underwriting profit to net investment income: Life & 81.2 & 81.9 & 83.2 & 79.9 & 84.0 & 45.0 \\
\hline Pre-tax profit ratio: Nonlife & 11.5 & 8.8 & 10.0 & 7.3 & 15.3 & 8.7 \\
\hline Pre-tax profit ratio: Life & 90.9 & 99.7 & 127.8 & 98.4 & 83.9 & 69.0 \\
\hline Pre-tax profits to shareholders funds: Nonlife & 13.7 & 11.0 & 11.2 & 9.5 & 19.3 & 7.0 \\
\hline Pre-tax profits to shareholders funds: Life & 133.3 & 202.0 & 149.0 & 84.7 & 98.9 & 56.0 \\
\hline Liquid assets to current & 39.2 & 41.9 & 64.7 & 50.5 & 43.1 & 49.8 \\
\hline Liquid assets to current liabilities: Life & 182.7 & 240.6 & 287.5 & 283.0 & 211.4 & 88.7 \\
\hline Statutory solvency cover: Nonlife & 303.0 & 277.8 & 327.9 & 277.2 & 176.4 & \\
\hline
\end{tabular}

Source: CBTT.

1/ Definitions of the ratios used in this table may be found in the FSI compilation guide (chapters 6 and 7). 


\section{The White Paper on the Financial System}

The White Paper seeks to achieve the following:

48. Banking sector: Compulsory adoption of International Financial Reporting Standards (IFRS) by all financial products and services institutions; consolidation of financial supervision in the hands of the central bank; a review of the tax treatment of the financial sector; the design and implementation of a competition policy for the financial sector; amending the FIA of 1993 to allow the central bank to supervise financial conglomerates; the setting of capital requirements on a consolidated basis; facilitating the development of an independent credit rating agency; and modernization of the credit bureau.

Progress made since the FSAP: ${ }^{15}$

49. FIA amendments have progressed to the drafting stage; the Regulatory Policy Council chaired by the CBTT was established in July 2005; fast-tracked amendments are with the Legislative Review Committee for review before taking the amendments to Parliament for debate; a Technical Working Group of the Caribbean Group of Supervisors has been established to address issues of harmonization of legislation in the region.

50. Insurance and pension sectors: Transfer of the regulatory and supervisory authority to the central bank (a law has been passed that transfers these functions, and regulations that would bring into effect such transfer are under development); revise the insurance legislation to meet the IAIS Core Principles; develop appropriate financial reporting standards; review the tax treatment of the insurance sector; enhance coordination and sharing of information with regional regulators; and initiate a feasibility analysis for an Insurance Fund. Regarding the pension sector, the White Paper proposes to consolidate and modernize the current regulatory framework including improvements in financial reporting standards, the strengthening of corporate governance, and the portability of pension rights.

Progress made since the FSAP:

51. Quarterly reporting for Insurance companies was rolled out on a live pilot in June 2005, which is scheduled for completion in December 2005. These reports will allow monitoring of the insurance sector by the CBTT on an ongoing basis; a dedicated team has been assigned toward the development of Pension Fund Guidelines in respect of administration, funding, benefit standards, disclosure, and corporate governance.

52. Capital market: Review and upgrade of the Securities Industry Act, corporate governance regulations, and information disclosure and reporting standards to ensure convergence to international best practices; establish an independent Regional Credit Rating

\footnotetext{
${ }^{15}$ The progress refers to the main developments as of August 2005.
} 
Agency; and the development of the infrastructure necessary for a more efficient primary and secondary sovereign bond market.

Progress made since the FSAP:

Sub-committee from the wider Professional Advisory Committee has been established to discuss mutual funds.

53. Others: The White Paper acknowledges that the regulations governing the Credit Union Sector are outdated and in need of an urgent overhaul that would include raising minimum standards in financial reporting standards and information disclosure. It also reports a legislative initiative to reform the Venture Capital Act of 1994 to, among other things, increase the range of investment instruments in which venture capital companies can invest, remove the restrictions on the type of shares that can be issued by venture capital companies, and eliminate the minimum capital requirement.

Progress made since the FSAP:

54. The Financial Stability Committee of the CBTT has been established and quarterly meetings have been convened, with CARTAC contacted for technical assistance; three guidelines have been issued and posted on the CBTT website: (i) Fit and Proper; (ii) Security of Customer Information; ; and (iii) Prudent Person Approach to Investment and Lending. 


\section{Stress Testing the Trinidad and Tobago Financial System}

55. Stress testing was carried out both at the systemic level and with respect to individual balance sheets for the commercial banks. For a number of reasons, however, it was considered highly desirable to extend the scope of stress tests to nonbank financial institutions. Commercial banks constitute less than 40 percent of the financial system-byassets. The insurance sector, which controls over 20 percent of the financial system, has been the fastest growing segment of the system over the last decade, besides being a major component of the business of some of the major conglomerates. In turn, the assumption by these conglomerates of a variety of financial businesses and portfolios under their management begs the question of how to quantitatively weigh the attendant diversification benefits accruing therefrom against the increased contagion risk forthcoming from a major adverse event.

56. Accordingly, major life insurance companies implemented a modified set of single factor market risk stress tests designed to calculate the impact of shocks on the market value of total assets. ${ }^{16}$ Financial groups (controlling over 50 percent of financial system assets) also carried out a set of single-factor, market risk stress tests on their consolidated balance sheets, using shock calibrations consistent with those applied to the banking system. Stress testing was based on latest available balance sheet data for financial institutions dated December 31, 2004.

57. The single-factor sensitivity tests for banks included testing for the net income impact of exchange rate and interest rate (yield curve position and slope) movements, the marketvalue-of-assets impact of property price movements, and estimation of credit default sensitivities to these shocks. Stress testing was constrained by the availability, frequency, and reliability of relevant macroeconomic and asset prices.

58. In addition to the single-factor sensitivity tests, two dynamic scenarios were designed to quantify the impact of major adverse events particularly relevant to Trinidad and Tobago. The first scenario involves an unexpected, substantial reduction in energy prices. The stress tests involve an estimation of the solvency impact of the combination of market and credit risk shocks generated by this event over an eight-quarter horizon. The second scenario involves a major business cycle shock that simultaneously affects Trinidad and Tobago's CARICOM partner economies, inflicting income and asset value losses on the domestic financial system's exposure to the CARICOM region.

\footnotetext{
${ }^{16}$ Owing to technical difficulties in estimating policyholder response to these shocks and the unavailability both to the regulator and the companies - of dynamic solvency models, it was not feasible to estimate the impact on market value of net assets. However, one of the insurance companies estimated the impact on an approximate measure of the solvency margin.
} 
Table A4. Trinidad and Tobago: Description of Stress Tests and Results

\begin{tabular}{|c|c|c|}
\hline Shock & \multicolumn{2}{|c|}{$\begin{array}{c}\text { Impact on Commercial Banks' CAR } \\
\text { (in percent) }\end{array}$} \\
\hline $\begin{array}{l}\text { I. Currency risk } \\
10 \text { percent depreciation } \\
30 \text { percent depreciation } \\
50 \text { percent depreciation }\end{array}$ & \multicolumn{2}{|r|}{$\begin{array}{l}-0.4 \\
-1.2 \\
-1.9\end{array}$} \\
\hline $\begin{array}{l}\text { II. Interest rate risk } \\
\text { Yield curve moves }+500 \text { bps } \\
\text { Yield curve moves }-300 \text { bps }\end{array}$ & \multicolumn{2}{|r|}{$\begin{array}{l}-0.2 \\
+0.7\end{array}$} \\
\hline $\begin{array}{l}\text { III. Property prices } \\
\text { Market value of real estate } \\
\text { portfolio declines } 20 \text { percent }\end{array}$ & \multicolumn{2}{|r|}{-3.8} \\
\hline \multirow[t]{2}{*}{ Scenario } & \multicolumn{2}{|c|}{$\begin{array}{c}\text { Impact on Commercial Banks' CAR } \\
\text { (in percent) }\end{array}$} \\
\hline & 2005 & 2006 \\
\hline $\begin{array}{l}\text { I. Energy price deterioration } \\
\text { Decline in all energy prices } \\
\text { yielding over } 8 \text { quarters: } \\
25 \text { percent drop in GDP; } \\
\text { Yield curve moves }+300 \text { bps } \\
40 \text { percent depreciation }\end{array}$ & $\begin{array}{lc} & -2.5 \\
\text { of which: } & \\
\text { credit losses: } & -2.4 \\
\text { losses on interest } & \\
\text { income: } & -0.1\end{array}$ & $\begin{array}{lc} & -3.3 \\
\text { of which: } & \\
\text { credit losses: } & -2.8 \\
\text { losses on interest } & \\
\text { income: } & -0.1 \\
\text { losses on open position: } & -0.4\end{array}$ \\
\hline \multirow{2}{*}{$\begin{array}{l}\text { II. Shock to regional asset values } \\
\qquad \begin{array}{l}\text { (a) } 100 \text { percent risk-weight on all } \\
\text { non-TTO, CARICOM area } \\
\text { sovereign securities; }\end{array}\end{array}$} & \multicolumn{2}{|c|}{$\begin{array}{c}\text { Impact on Commercial Banks' CAR } \\
\text { (in percent) }\end{array}$} \\
\hline & \multicolumn{2}{|r|}{-0.1} \\
\hline $\begin{array}{l}\text { (b) Loss of } 25 \text { percent of market } \\
\text { value on regional asset portfolio. }\end{array}$ & \multicolumn{2}{|r|}{-1.3} \\
\hline
\end{tabular}

Source: IMF and CBTT staff calculations. 


\section{OBSERVANCE OF \\ STANDARDS AND CODES-SUMMARY ASSESSMENTS}

\section{Summary}

The annex contains summaries of the detailed assessment of international financial sector standards conducted within the framework of the FSAP. The assessments have helped to identify the extent to which the banking regulatory and supervisory systems and the systemically important payment systems infrastructure in TTO meet the well-accepted international practices.

The assessment of the Basel Core Principles for Effective Banking Supervision was undertaken by Andy McNab of the U.K. Financial Services Authority and Chua Kim Leng of the Monetary Authority of Singapore, and the CPSS Core Principles for Systemically Important Payment Systems was carried out by Massimo Cirasimo (Senior Financial Sector Specialist, World Bank). The assessment of TTO's supervisory compliance with the international standards in insurance (IAIS Insurance Core Principles) and securities (IOSCO Objectives and Principles of Securities Regulation), were not undertaken in view of the ongoing legislative and institutional reforms. The sectors are, however, significant in light of the structural linkages with the banking sector through the financial groups and conglomerate structures. This aspect needs to be kept in view while examining the level of technical compliance with the BCP, which is overall of a reasonable standard.

The CBTT, which in 2004 has taken on the supervisory functions of insurance and pension sectors, in addition to banking and other licensed financial institutions, faces the challenge of building on the institutional capacity in the banking area and rapidly expanding it to insurance, pension, and systemically relevant financial groups and conglomerates. Considerable progress is under way in legal reform, and strengthening supervisory practices in banking and insurance areas. Legal limitations, however, continue to impede the CBTT's efforts at introducing consolidated supervision, enter into cooperative supervisory information sharing arrangements, and in strengthening supervisory reporting (reporting on a consolidated basis) across all licensed financial institutions, insurers, and pension firms.

In the payment systems area, in recent years, the CBTT has played a very active role in the launch of a new automated interbank payment system, which has significantly improved payment arrangements in the country. The CBTT must, however, finalize the reform effort to address the pending issues. 


\section{Compliance of the Basel Core Principles for Effective Banking Supervision}

\section{General}

59. The assessment of TTO's compliance with the Basel Core Principles for Effective Banking Supervision (BCP) was carried out as of March 2005. This work focused almost entirely on the banking supervision function of the CBTT.

60. The assessment was performed based on the BCP Methodology, which was published by the Basel Committee on Banking Supervision in October 1999. The CBTT submitted a self-assessment of the Core Principles prior to the mission. The main sources for the assessment included the laws and supervisory regulations and guidelines concerning credit institutions. Additionally, the assessors received relevant materials from the CBTT, including inspection manual, risk assessment, and examination reports. A key piece of material provided by the authorities was the March 2005 draft of proposals to amend the 1993 FIA and the Central Bank Act 1964 (CBA). As well as extensive discussions with banking supervisory staff within the CBTT, meetings also took place with representatives from the main commercial banks, the bankers association and an international accounting firm. The assessors received excellent cooperation from all those they met.

61. The assessment is essentially a snapshot of the supervisory regime prevailing in March 2005. The assessment of compliance with each Principle was made on a qualitative basis and in accordance with the criteria laid out in the BCP Methodology. In several cases, all essential criteria were generally met without any significant deficiencies. However, with regard to the specific structure of the TTO financial system and the dominance of the financial conglomerates and active cross-border financial intermediation, it may be noted that the essential criteria might not always be sufficient to achieve the underlying objective of the Principle. While no calibration was made to the assessment framework, the authorities need to continue to strengthen the quality of compliance.

62. The assessors noted that the vast majority of the shortcomings will be addressed once proposed changes to the FIA and CBA are enacted. These proposals are at an advanced stage and the authorities are confident that the legislative changes will come into force by December 2005. This would result in a significant strengthening of compliance with the Core Principles.

\section{Institutional and Macroprudential Setting, Market Structure-Overview}

63. The roles and responsibilities of the CBTT with regard to the supervision of the banking sector are encapsulated in the FIA, the CBA and the Financial Institutions (Prudential Criteria) Regulations. The legislation provides for the following: (i) regulation of banks and other financial institutions which conduct business of a financial nature; (ii) roles and responsibilities of the CBTT with respect to the supervision of licensees; (iii) inspection, investigation and winding up of licensees; and (iv) emergency powers of the CBTT. Under the FIA, the CBTT is the sole licensing and supervisory authority for banking institutions. 
The supervisory responsibilities of the CBTT are to protect the interests of depositors, to ensure the safety and soundness of licensees and to ensure that licensees comply with the relevant laws and regulations. Generally, the FIA and Prudential Regulations prescribe the minimum prudential standards that licensees must meet. These include limits on large exposures, related lending and investments, as well as minimum capital requirements.

64. There are six commercial banks in TTO: two are subsidiaries of large, international financial conglomerates; one is state-owned; ${ }^{17}$ and the remaining three are domestically owned and privately held, including two of the sector's largest players who together control about 60 percent of banking assets. The sector's assets grew at an annual average rate of 13 percent over the last 5 years, totaling TT $\$ 50$ billion at end-2004. These banks held 35 percent of total financial assets in 2004 compared to 43 percent in 1999. This is reflective of a situation where growth in other parts of the financial system has consistently outstripped that of banks over the last five years.

65. Banks are well capitalized and adequately provisioned for coverage of nonperforming assets. ${ }^{18}$ Current capitalization levels, both at individual banks as well as at the sector level make them resilient to a variety of unexpected, single-factor macroeconomic shocks, such as large one-off changes in interest rates and exchange rates, as well as to modest increases in average credit risk. Income statements indicate that profits are healthy and that the proportion of noninterest income has grown steadily over the last five years, from 36 percent in 1999 to over 47 percent by September 2004. This is consistent with the increasing investment outlay of banks toward acquiring equity stakes in other financial institutions.

66. There has been a significant increase in lending activity in 2004, following a prolonged period of stagnation, explained primarily by the purchase for excess cash reserves, ${ }^{19}$ pre-existing mortgage and real estate loans made by other entities in the banks' parent groups. Net open positions of most banks are within the required 10 percent-of-capital limits. A large proportion of the banks' non-TTO investment outlay is concentrated in the CARICOM area. While the banking system's direct regional exposure is no more than 5 percent of total capital, the total exposure could be greater if banks' equity stakes in

\footnotetext{
${ }^{17}$ This bank owes its existence to the consolidation of three failed banks in the early 1990s.

18 Available data place average capital adequacy of the commercial banking system at 23 percent as of end-December 2004. Capital adequacy ratios of individual merchant banks and finance companies licensed under the FIA are also-barring one exception - uniformly in excess of the minimum 10 percent requirement, albeit not as high in magnitude as the commercial banks. The statement is meant to imply that banks appear immune to the direct impact of single-factor shocks, but may yet be more vulnerable through indirect impact forthcoming from their financial links with other parts of the system, particularly through parent conglomerates where they belong to a financial group.

${ }^{19}$ Excess reserves are explained by the recent reduction in cash reserves requirements for commercial banks from 18 to 11 percent.
} 
domestic financial institutions, which are exposed to the region, and purchases of options on regional debt are included.

\section{General Preconditions for Effective Banking Supervision}

67. The assessment of these preconditions was formed primarily on the basis of the views of the authorities and private sector participants interviewed by the assessors.

68. Macroeconomic Issues - the TTO economy has been growing rapidly during the last three years with the expansion of the energy sector leading to annual overall real GDP growth in the range of $6 \frac{1}{2}$ to $13 \frac{1}{4}$ percent. Inflation has generally been low, the fiscal position is in surplus, debt is at manageable levels, and foreign exchange reserves are rising rapidly. The energy sector accounts for about 40 percent of the economy's output and about half of government revenue. The boom in the energy sector has resulted in the accumulation of significant savings, which have not been matched by domestic investment, resulting in record high current account surpluses. Meanwhile the nonenergy sector has been growing at around 4 percent. The high reliance in the energy sector exposes the economy to volatility in energy prices. In the absence of a revenue stabilization arrangement, this volatility has resulted in procyclical policies.

69. Legal Environment - TTO has a relatively strong and stable legal system and the rule of law and respect for the judiciary is high. Contracts are, largely, enforceable. The legal framework governing the taking and enforcing of security appears to be generally sound, although the property registers are in need of updating and the court process is sometimes protracted. Reforms to the country's land registration procedures are about to become effective and should greatly improve the system of land registration and the enforcement of secured interests in land. The Company Registry is also currently undergoing a computerization project, which, when completed, should improve the efficiency of its processes considerably. Once a number of draft laws have been enacted, TTO should have a sound legal foundation on which to develop an internationally competitive financial sector. However, the country would benefit from a comprehensive insolvency law that incorporates a procedure for the reorganization or administration of insolvent companies.

70. Resolution of problems in banks - The CBTT has a range of supervisory and regulatory measures to deal with institutions that fail to perform in the best interests of depositors, creditors and the public. These measures range from less formal supervisory measures, such as closer monitoring, informal directions to the institutions' management and higher frequency of on-site examinations, to severe regulatory actions, such as assuming control of the institutions and in the worst case scenario their orderly liquidation. In addition, the CBTT has published an Exit Policy document, which articulates the policies and procedures for the prompt and orderly resolution of problems in financial institutions. The document sets out a series of graduated supervisory and regulatory measures for addressing 
at an early stage potential problems in institutions as well as how failing institutions should be treated. ${ }^{20}$

71. Public Safety Nets - Bank deposits are covered by an explicit deposit insurance scheme (Deposit Insurance Corporation) that is jointly funded by the central bank and the commercial banks themselves. This protection amounts to a maximum of TT $\$ 50,000$ (approximately US\$8000) of each depositor's account in each bank.

\section{Main Findings}

72. The Basel Core Principles for Effective Banking Supervision (the BCPs) have been grouped into seven major categories as follows: (i) preconditions for effective banking supervision; (ii) licensing and structure; (iii) prudential regulations and requirements; (iv) methods of ongoing supervision; (v) information requirements; (vi) formal powers of supervisors; and (vii) cross-border banking. The following summarizes the main findings in terms of these seven categories.

\section{Objectives, autonomy, powers, and resources (CP 1)}

73. The general legal framework for TTO's banking system appears to be adequate. The CBA and FIA empower the CBTT to license and supervise banks and other financial institutions, revoke licenses, enforce legal and prudential standards, impose legal sanctions and penalties, and obtain information from licensees for supervision purposes. While the FIA does not empower the CBTT to establish prudential laws, the Finance Minister is empowered to do so after receiving recommendations from the CBTT. Such regulations have the force of law.

74. The CBTT has statutory independence under the CBA. Even though specific permission of the Minister of Finance is needed for certain transactions (e.g., making of regulations), most decisions pertaining to authorization of licensees, day-to-day supervision and revocation of licenses, lie with the CBTT or its Board of Directors. The CBTT is self-financing and its annual budget is approved by the Board of Directors.

75. The President of TTO appoints both the Governor, upon the recommendation of the Minister of Finance, and the Inspector of Financial Institutions, upon the recommendation of the Governor. The President also appoints all the members of the Board of Directors of the CBTT. The Board members comprise the Governor (Chairman of the Board), Deputy Governor, Permanent Secretary (Finance) and other suitable individuals who do not, directly or indirectly, engage in any business or activities under the CBTT's purview. The CBA confers the CBTT and its staff immunity from lawsuits for actions taken while discharging their duties under the CBA or FIA in good faith and without negligence.

\footnotetext{
20 This is an encouraging first step in clarifying CBTT's exit policy for weak banks. However, substantial improvements are still necessary therein to achieve this goal.
} 
76. Under existing laws, the CBTT is unable to formally share supervisory information with either domestic or foreign regulators. This deficiency will be addressed following the proposed amendments to the FIA, to enable the CBTT to share relevant information about a licensee with other regulators, both domestic and foreign, for supervisory purposes, as well as with law enforcement agencies to combat money laundering.

\section{Licensing and structure (CPs 2-5)}

77. The FIA adequately defines banking business, business of a financial nature and permissible activities of licensed institutions. The Act also prohibits the use of the word "bank" or any variation of the word except with the approval of the CBTT.

78. The CBTT is both the licensing and supervisory authority. In the licensing process, the CBTT obtains information on ownership structure, strategic and business plan, financial statements, experience of the board of directors and management, framework of risk management, and the home supervisor's assessment of the applicant in the case of a foreign bank. The CBTT then evaluates the applicant's financial strength, the suitability of shareholders, directors and management, extent of support from shareholders, as well as the home or host supervisory regime where appropriate. The licensing criteria are consistent with those applied to ongoing supervision.

79. Under the FIA, a prospective controlling shareholder is required to obtain a permit from the CBTT prior to acquiring or controlling 25 percent or more of the voting shares in a licensed financial institution. In determining whether a permit should be granted, the CBTT takes into account whether the proposed shareholder is a fit and proper person and whether the shareholder would prejudice the interests of depositors. The 25 percent threshold is assessed to be high by international standards. In addition, the FIA does not require immediate notification or approval for changes in the shareholding of a licensee. These areas are proposed to be addressed in the revisions to the FIA.

\section{Prudential regulations and requirements (CPs 6-15)}

80. Prudential rules and requirements are set out in the FIA as well as guidelines issued by the CBTT from time to time. Overall, prudential requirements are relatively sound, except for the few deficiencies discussed below. Credit, market, liquidity and other material risks of licensed institutions are independently evaluated and verified by the CBTT through regular on-site examinations and off-site monitoring. Risk management processes, bank policies, procedures and practices related to the ongoing management of these risks and regulatory compliance are also assessed periodically.

81. In terms of capital adequacy requirements, there are some shortcomings. With respect to credit risk, the risk weight prescribed by the CBTT for non-OECD foreign sovereign debt is inconsistent with the Basel Capital Accord, while market risk requirements have not been adopted except for the 10 percent foreign exchange capital charge. In addition, capital adequacy ratios are not calculated and applied on a consolidated basis and a bank's 
investments in unconsolidated banking and financial subsidiaries are not required to be deducted from the computation.

82. There are inadequate regulations and operational policies pertaining to loan review, asset classification, provisioning and policies for problem credits. Additionally, the single borrower lending limits are high by international standards and licensees are not required to report large exposures to the CBTT on a regular basis for monitoring. The regulatory requirements pertaining to connected lending should also be strengthened. Specifically, there are no laws or regulations to prohibit licensees from granting more favorable credit terms to a related borrower, and the 5 percent unsecured lending limit to a director appears high by international standards. There are proposals to address these areas in the revisions to the FIA. However, in practice the CBTT examiners pay close attention to the banks' credit exposure, connected lending and credit risk management capabilities.

\section{Methods of ongoing supervision (CPs16-20)}

83. The CBTT's banking supervision department is structured into teams, which are charged with the oversight of particular institutions. Thus, there is no split between off-site and on-site work; both are conducted by these teams. At the time of the assessment, a departmental reorganization was in hand, which would, inter alia, lead to the creation of a complex group team to examine the operations of the country's financial conglomerates. The use of a team approach assists the supervisory process and notably the risk assessment framework utilized by the CBTT. During on-site examinations, particular attention is paid to banks' risk management arrangements, internal controls, treasury operations and asset quality. Off-site data are used to update individual bank risk assessments. Some weaknesses exist in the comprehensiveness of off-site data required for a consolidated review, but these are in the process of being addressed.

84. In addition to the on-site work conducted in relation to the development of risk assessments, the supervisors hold regular quarterly meetings with bank management, which helps in determining the quality of management. At present there is an expectation (but not an obligation) that bank management would inform the CBTT of any breaches of the FIA. Currently the validation of off-site data is conducted during on-site examinations by the CBTT's staff. However, the CBTT intends to make increasing use of banks' external auditors in this regard, in particular by requiring an audit sign off on end of year financial returns submitted to the CBTT.

\section{Information requirement (CP 21)}

85. By law, banks must maintain adequate accounting and other records and adequate systems and controls. Whilst the accounting standards to be adopted by banks are not prescribed by the CBTT, in practice all banks are audited to International Accounting Standards and employ the major international accountancy firms to conduct external audits. Legislation requires banks to publish audited financial statements within three months of their year-ends. Moreover, there is an obligation on banks to provide copies of the audited 
statements upon request and to have copies available for inspection at all branches.

Currently, the CBTT does not have the power to oppose the appointment of a bank's external auditors, or the power to establish the scope and standards to be achieved in external audits. Legislative change on these points will be considered as part of the proposals to amend the FIA.

\section{Formal powers of supervisors (CP 22)}

86. The FIA and CBA give the CBTT a number of powers in relation to licensed banks. They include revocation of licenses, the placing of restrictions on banks' activities and the issuing of "cease and desist" orders. As mentioned earlier, the CBTT has published an "exit policy" for licensed financial institutions. The focus in this document provides for the likely responses that the CBTT will set in motion to deal with deteriorations in capital adequacy, asset quality, competency of management, risk management arrangements, profitability and liquidity. However, the CBTT itself recognizes that its powers of remediation need to be further strengthened and its enforcement powers enhanced. Experience has shown that there are limitations to existing powers, for example in instances where institutions are not financially strong, but are meeting the minimum legal requirements.

\section{Cross-border banking (CPs 23-25)}

87. The most significant weakness in methods of cross border banking (and ongoing supervision-BCPs 16-20) is the lack of consolidated supervision powers, which hampers the supervision of the financial conglomerates in particular, which have expanded regionally over recent years. To date, unofficial means have been employed to obtain an understanding of the global risk profile of these institutions. Attempts have also been made to influence the global risk appetite of groups and seek remedial action where weaknesses have been detected, but on a cooperative rather than legal basis with the groups. Proposals to amend the FIA, however, address this and once enacted should provide the CBTT with the ability to conduct consolidated and group supervision, both within TTO and globally.

88. Currently, there are also substantial constraints on information sharing with overseas supervisors. Under the existing legislation information about individual bank's operations can only be shared with home country supervisors provided that the bank concerned is so advised. Again, the proposals to amend the FIA will address this weakness and introduce information sharing arrangements, which are in line with international best practice. Foreign banks are only permitted to operate in TTO through subsidiaries. Consideration is being given as to whether branch operations will be permitted in the future. There is no material difference in the supervisory treatment between domestic and foreign owned institutions. Both are subject to the same prudential norms and risk based supervisory process. 


\section{Recommended actions and authorities' response to the assessment}

\section{Recommended actions}

Table 1. Recommended Actions to Improve Compliance with the Basel Core Principles

\begin{tabular}{|c|c|}
\hline Reference Principle & Recommended Action \\
\hline $\begin{array}{l}\text { All CPs except } 1.4,2,3,7 \\
8,12-14 \& 17\end{array}$ & $\begin{array}{l}\text { The FIA amendments should be enacted with the minimum of further delay as } \\
\text { they affect most of the CPs and are fundamental to the overall effectiveness of } \\
\text { supervision. }\end{array}$ \\
\hline CP1.2 & $\begin{array}{l}\text { Ensure the reorganization of the FISD does not lead to a misallocation of } \\
\text { supervisory resources and expertise. External specialist recruitment may } \\
\text { become necessary as risk based and consolidated supervision is introduced. }\end{array}$ \\
\hline $\mathrm{CP} 3$ & $\begin{array}{l}\text { Consider conducting independent screening checks with law enforcement } \\
\text { agencies and other relevant domestic agencies on controlling shareholders, } \\
\text { directors, or managers. }\end{array}$ \\
\hline CP5 & $\begin{array}{l}\text { Consider a reduction in the percentage level of investments, which requires the } \\
\text { CBTT's approval. }\end{array}$ \\
\hline CP6 & $\begin{array}{l}\text { Change the CAR computation with regard to the treatment of non-OECD } \\
\text { sovereign exposures and investment in financial subsidiaries to achieve Basel I } \\
\text { compliance. }\end{array}$ \\
\hline CP7 \& CP8 & $\begin{array}{l}\text { Consider issuing a guideline on asset classification and provisioning. Release } \\
\text { the draft guideline on Prudent Person Approach to Investment and Lending. }\end{array}$ \\
\hline CP6 \& CP12 & $\begin{array}{l}\text { Develop and implement a regime to capture fully market risk within CAR } \\
\text { computation. }\end{array}$ \\
\hline $\mathrm{CP} 14$ & Issue the draft guideline on Corporate Governance with the minimum of delay. \\
\hline CP15 & $\begin{array}{l}\text { The CBTT, in conjunction with the financial intelligence unit, might well } \\
\text { consider constructing a centralized database of known terrorist suspects for use } \\
\text { by the licensees, as is the case in a number of countries. } \\
\text { Consider, as part of its Guideline, requiring licensees to formulate policy } \\
\text { statements on ethics and professional behavior that can be clearly } \\
\text { communicated to all staff. }\end{array}$ \\
\hline $\mathrm{CP} 17$ & $\begin{array}{l}\text { Licensees should be required legally to inform the CBTT of any breaches of the } \\
\text { FIA or other relevant legislation. In the context of the draft proposals to amend } \\
\text { the FIA, consideration needs to be given to the inclusion of a clause to this } \\
\text { effect. }\end{array}$ \\
\hline $\mathrm{CP} 18$ & $\begin{array}{l}\text { The CBTT should design and implement system of reporting for classified } \\
\text { loans and advances. }\end{array}$ \\
\hline $\mathrm{CP} 21$ & $\begin{array}{l}\text { Ensure the proposed FIA amendments cover the CBTT's right to oppose the } \\
\text { appointment of external auditors and spell out exactly the required auditing } \\
\text { standards. } \\
\text { Consider requiring external auditors to report material concerns simultaneously } \\
\text { to the Boards of institutions as well as to the CBTT. }\end{array}$ \\
\hline
\end{tabular}




\begin{tabular}{|l|l|}
\hline \multicolumn{1}{|c|}{ Reference Principle } & \multicolumn{1}{c|}{ Recommended Action } \\
\hline CP22 & Remove the concept of supervisory forbearance from the Exit Policy document. \\
\hline CP23 & $\begin{array}{l}\text { Consider proposals to amend the FIA in respect of the CBTT's right to require } \\
\text { closure of, or impose conditions on, overseas operations of licensees. }\end{array}$ \\
\hline CP24 & $\begin{array}{l}\text { Renewed impetus should be given to the "fast tracking" of legislative changes } \\
\text { on the CBTT's information sharing powers, or the CBTT should inform other } \\
\text { signatories to the regional Memorandum of Understanding of the legal } \\
\text { constraints it faces in relation to information sharing. }\end{array}$ \\
\hline CP25 & $\begin{array}{l}\text { CBTT to determine the materiality of remedial action and the circumstances, } \\
\text { which would prompt the CBTT to disclose information to home supervisors. }\end{array}$ \\
\hline
\end{tabular}

\section{Authorities' response}

89. Authorities had the opportunity to review this report and expressed agreement with its content. The factual corrections provided were accepted and incorporated in the document. In addition, the authorities have responded as follows: "The proposed FIA amendments are at an advanced drafting stage and are scheduled to be tabled in Parliament in October 2005. The concerns in CPs 5, 17, 21, 23, 24, and 25 are being addressed in the FIA amendments. FISD was reorganized in June 2005 and resources and expertise have been effectively allocated as per the reorganization plan. The supervisory approach is now integrated and continues to be risk based, with the development and implementation of a consolidated supervisory framework scheduled for October 2005. The concerns in CPs 3, 7, 8, and 18 are being addressed through policy and procedural changes within FISD. The Prudent Person Approach to Investment and Lending guideline was issued in May 2005 and the Corporate Governance guideline is being finalized. A Code of Ethics is also a standard that has been adopted by the industry. A project team is already reviewing the methodology used for capital adequacy computations. The team's mandate has been extended to the development of a methodology for computations on a consolidated basis." 


\section{CPSS CORE Principles For Systemically IMPORTANT PAYMENT SystemS}

\section{General}

90. The assessment of systemically important payment systems in TTO is based on the Committee for Payment and Settlement Systems (CPSS) Core Principles (CPs) for Systemically Important Payment Systems (CPSIPS). The assessment was carried out with reference to the state of the payment systems as in February 2005.

91. One systemically important system was assessed - the recently launched Real Time Gross Settlement (RTGS) system (safe-tt) — that allows movements of funds among the accounts of financial institutions at the central bank. Although the check clearinghouse is still processing large value payments, the CBTT and the banks are determined to reduce the systemic importance of this system in the following months. Securities settlement systems were not assessed in detail with the CPSS-IOSCO recommendations for Securities Settlement Systems because, although there is one stock exchange operating in the country (TT Stock Exchange), the securities market is not particularly active. However, some recommendations for the improvement of securities custody and settlement systems have been provided.

\section{Institutional and Market Structure ${ }^{21}$}

92. The assessment of the main payment systems in TTO, carried out by a World Bank team in 2000, confirmed that there was a need for a more sound and efficient payment system. This was especially in the context of the evolving market conditions at both domestic and international level. On the domestic side, the financial sector and the economic agents demanded more efficient ways to make payments. On the international side, there was a growing need for efficient and sound payment systems for supporting cross-border financial transactions. In addition, following worldwide trends, some countries in the Caribbean were moving fast toward the implementation of a comprehensive payment system reform. The mission acknowledged that the CBTT, the other regulators and the market participants were already engaged in the exercise of reviewing payment system arrangements and fully encouraged the effort. In addition, the mission supported the overall objectives of the payment system reforms, as stated by local authorities, namely the achievement of efficient, diverse, automated and safe ways to make payments in the country.

93. Following this, the CBTT engaged itself in a series of actions to address all pending elements related to payments system reform. These issues were debated and agreed upon with payments system stakeholders and put into a strategic document. The milestones of the reform project were as follows: (i) establishment of a project team within the CBTT;

\footnotetext{
${ }^{21}$ In FSAP/FSSA reports, information on the institutional, macroprudential setting, and market structure and specific risk factors would be contained in other parts of the reports with these sections containing only the relevant highlights in summary form.
} 
(ii) creation of a National Payment System Council to provide a forum for discussion to all stakeholders; (iii) preparation of a long term vision and adoption of a strategic approach; (iv) identification and hiring of external technical support to the project (payment system consultants and World Bank); (v) preparation of draft laws to support the reform of the legal framework for payment systems; (vi) implementation of the systems; and (vii) establishment of the oversight function.

94. The CBTT and the other stakeholders have achieved significant results in the reform of the payments system. Among them, the most important are: (i) launch of a Real Time Gross Settlement (RTGS) system (safe-tt), which went live in October 2004. Safe-tt is a modern system and has several tools for managing liquidity pressures (such as queues and intraday credit facilities); (ii) launch of a custody and settlement system for government securities (GSS), which went live for Bills and Notes in December 2004 and for Bonds in February 2005; (iii) migration of all banks and the central bank to SWIFTNET; and (iv) creation of a Virtual Private Network (VPN), called EXTRANET, by the CBTT, which provides the banking community in TT with a safe and secure network that allows them to share information and carry out several operations. For example, the EXTRANET provides participants in safe-tt with a facility to monitor their settlement accounts and gives them a number of tools to help them manage those accounts and manage their intraday liquidity. It also provides a secure messaging service from the CBTT to safe-tt participants. Government intermediaries are able to participate in securities actions over the EXTRANET;

(v) preparation of all laws and by-laws for a comprehensive reform of the legal framework and the establishment of the payment system oversight function of the CBTT; (vi) launch of a securities settlement system by the TT Stock Exchange in 2003; and (vii) launch of an Automated Clearinghouse, owned by commercial banks, expected in 2005.

\section{Assessment of the CPs and Central Bank Responsibilities: Main Findings}

95. The RTGS system (safe-tt) is owned and operated by CBTT. RTGS Payments are sent to the system by participants via SWIFT. The system identifies the sending bank and checks its settlement account for funds; if funds are available, the account is debited and the receiving bank's account is credited in safe-tt. A copy of the sending bank's SWIFT message is automatically sent to the receiving bank. The participating banks are able to view their pending and settled amounts on their browser workstation.

\section{Legal foundation (CP I)}

96. The legal framework for payments and securities settlement presents some important weaknesses. The legal basis is incomplete in that it supports paper-based payments systems but lacks the elements required for the operation of modern payments system.

\section{Understanding and management of risk (CPs II-III)}

97. The safe-tt has in place appropriate mechanisms to manage credit and liquidity risks that are available to and well understood by all participants. 


\section{Settlement (CPs IV-VI)}

98. The safe-tt is an RTGS and allows for real time settlement during the day of value on the books of the CBTT.

\section{Security and operational reliability, and contingency arrangements (CP VII)}

99. The manuals and procedures for business continuity are under preparation and a hot site is being prepared at a remote central location from which safe-tt can be operated in the event that the main site is inaccessible or there is system failure at the main site.

\section{Efficiency and practicality of the system (CP VIII)}

100. The safe-tt has been launched recently and participants in general have expressed satisfaction on its operations. Some minor efficiency issues might have to be addressed over time as the system matures.

\section{Criteria for participation (CP IX)}

101. Participation in safe-tt is open to commercial banks. Participant Criteria and Conditions are set out in the Operating Rules. Rules for withdrawal and suspension of a participant are defined in the Operating Rules.

\section{Governance of the payment system (CP X)}

102. The system is operated by the central bank and internal organizational arrangements are in place for its management. Although there are no formal users' groups, the CBTT established a National Payment System Council as a forum of discussion on payment system matters. The system complies with most of the CPSIPS and broadly observes CP X.

\section{Central Bank Responsibilities in applying the CPs}

\section{Responsibility A-Payment system objectives and disclosure}

103. The CBTT undertook an examination of the existing legislation related to payments and embark on an upgrade of existing laws and the introduction of laws specific to payment systems. This legal reform will include a formal empowerment to the CBTT to exercise its payment system oversight function. The objective is to have a system that is efficient, minimizes risk, is convenient and economical, and that measures up to the international best practices. The reform program is being approached in a strategic manner, taking a holistic view of all elements. The objective is to ensure that all elements will be integrated and interlinked to the greatest degree possible. Further, with a view to achieving maximum synergy, it is intended to implement the various elements in a concurrent manner as far as possible. A draft Policy Statement is being prepared on Payments System Oversight. 


\section{Responsibility B-Ensure SIPS compliance with the core principle.}

104. The CBTT performed its own assessment of its existing systems against the core principles and in upgrading its systems has sought to address weaknesses wherever they existed. Through automation of several of its processes and introducing automatic links with the settlement system, safe-tt, many of the risks inherent with paper-based systems have been reduced or eliminated. The check clearinghouse is still of some systemic importance and does not fully observe the CPSIPS.

\section{Responsibility $C$-Establish an oversight function to observance of the Core Principles by other systems}

105. Currently, there are no systemically important payment systems in TTO outside the central bank. The CBTT intends to oversee the new ACH, given its expected importance for the payments system in the country. The CBTT is a member of the TTIPS committee, which is responsible for the establishment of the ACH. Part of the role of the Bank's representatives is to ensure that the ACH adheres to the Core Principles. The CBTT is establishing its oversight function. The draft Policy statement will include recommendations for the organizational structure of the oversight department. On completion of the reform in 2005, the oversight activities will commence. The Payments System Oversight function is to be carried out by an autonomous department. The department is currently staffed with a Manager, one graduate member of staff and an administrative assistant. The department is currently engaged in internal and external system implementation activities as they relate to payments system reform. The detailed staffing arrangements for oversight are to be determined on completion of the reforms.

\section{Responsibility D-Cooperation with other central banks and other relevant domestic or foreign authority.}

106. The CBTT and other regulators cooperate on payment system issues in the context of the Payment System Council, established by the CBTT in 2002 as a forum for discussion and to steer the reform effort. In particular, the CBTT and the TTSEC have established a joint project team to manage the reform project. There is a sharing of information and a coordination of onsite visits with the Financial Institutions Supervision Department (FISD) is planned for Payments Systems Oversight. Consultation with the Securities and Exchange Commission and the Stock Exchange ensures that there is exchange of information and coordination of activities when necessary to avoid duplication of effort. The FIA is being amended to allow the sharing of information among regulators. At the international level, the CBTT is particularly active both at the regional level, in the context of the Working Group on Payment System Issues of the central banks of Latin America and the Caribbean, and at the international level, in the context of fora organized by the CPSS, the World Bank, etc. 


\section{Recommended actions and authorities response}

Table 2. Recommended Actions to Improve Observance of CPSS Core Principles and Central Bank Responsibilities in Applying the CPs

\begin{tabular}{|c|c|}
\hline Reference principle & Recommended action \\
\hline $\begin{array}{l}\text { Legal foundation } \\
\quad C P I .\end{array}$ & $\begin{array}{l}\text { Pending legal issues are being addressed and the draft legislation is } \\
\text { complete and detailed. Should legislation be passed as drafted, the } \\
\text { legal framework for payment systems would be robust and the } \\
\text { RTGS system would fully observe CP I. }\end{array}$ \\
\hline $\begin{array}{l}\text { Security and operational reliability, and } \\
\text { contingency arrangements } \\
\quad C P V I I\end{array}$ & $\begin{array}{l}\text { Need to fully operationalize the hot site and speed up the } \\
\text { completion of the manuals. }\end{array}$ \\
\hline $\begin{array}{l}\text { Efficiency and practicality of the system } \\
\quad C P V I I I\end{array}$ & $\begin{array}{l}\text { The CBTT will have to convene system participants to discuss any } \\
\text { changes required to further enhance the efficiency of the system. } \\
\text { Pricing policies should be carefully formulated, discussed with } \\
\text { system participants, and used to rearrange payment transactions in a } \\
\text { more efficient and secure way, in particular by removing large value } \\
\text { checks from the check clearinghouse. }\end{array}$ \\
\hline $\begin{array}{l}\text { Criteria for participation } \\
\quad C P I X\end{array}$ & $\begin{array}{l}\text { The CBTT will have to clarify explicitly its policy regarding access } \\
\text { and eventually consider the inclusion of other institutions into the } \\
\text { RTGS system. }\end{array}$ \\
\hline $\begin{array}{l}\text { Governance of the payment system } \\
C P X\end{array}$ & $\begin{array}{l}\text { Formal users group should be created as a matter of urgency to } \\
\text { address all system needs also from the participants' perspective. } \\
\text { Since signs of financial stress are likely to manifest themselves in } \\
\text { the payments system, it is important that clear guidelines be } \\
\text { developed on what triggers are invoked in the event of a bank or a } \\
\text { systemic failure and on reporting and monitoring requirements of } \\
\text { the payment system department. A formal interdepartmental } \\
\text { committee, chaired by a Deputy Governor, should be formed within } \\
\text { the CBTT to address all issues related to the payments system, } \\
\text { which affect multiple departments. It needs to be noted that } \\
\text { interdepartmental committees do exist within the CBTT and might } \\
\text { be used to cover payment system matters. }\end{array}$ \\
\hline
\end{tabular}




\begin{tabular}{|c|c|}
\hline Reference principle & Recommended action \\
\hline $\begin{array}{l}\text { Central Bank Responsibilities in applying the } \\
\text { CPs } \\
\quad \text { Responsibilities } A-D\end{array}$ & 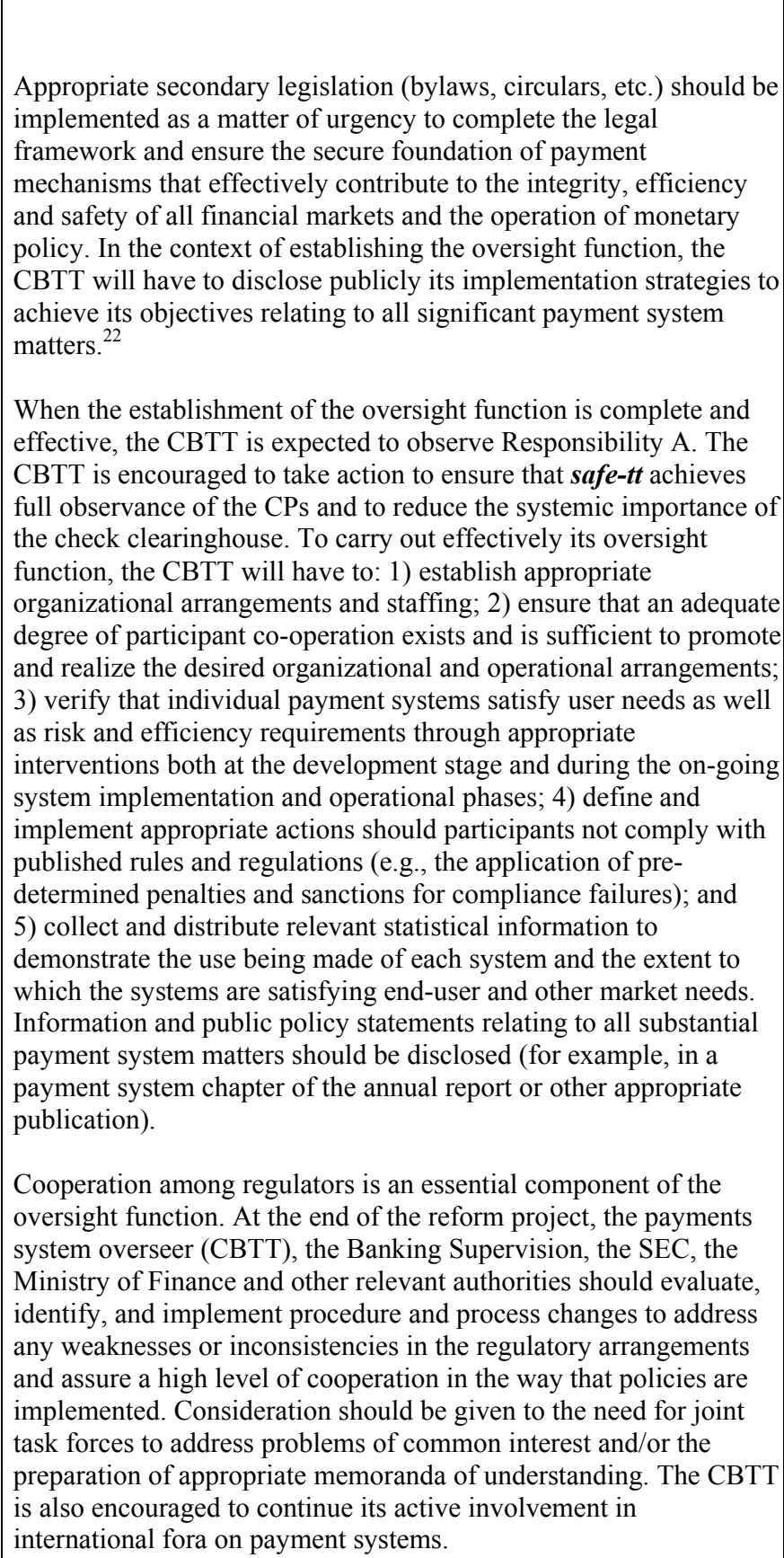 \\
\hline
\end{tabular}

${ }^{22}$ Operating Rules and Regulations were signed by all participants in 2004. 
107. In the context of establishing the oversight function, the CBTT should disclose publicly its implementation strategies to achieve its objectives relating to all significant payment system matters. With regard to policy objectives, the mission suggests that consideration be given to a broadening of scope beyond the two traditional main objectives of efficiency and reliability of payment systems to a wider set of issues including the promotion of competition in the payment services market, and the protection of consumer interests by the government. ${ }^{23}$ These objectives might be pursued by the CBTT, as overseer of the payments system, especially in those cases not embraced by other regulatory or supervisory authorities. With regard to the scope of its oversight role, the mission suggests that the CBTT apply its oversight authority over all payments and securities settlement systems in the country, both systemically important and retail systems, since the latter are especially important in supporting economic activity and the public trust in money. In performing the oversight function, the CBTT should ensure that transparency of policies and conditions for payment services offered be available to the population of Trinidad and Tobago at all times. The central bank, banks and other financial institutions should be encouraged to provide information to the public on the services they offer in the payments system. Moreover, while arrangements for the resolution of conflicts are spelt out in the rules, it is important also to ensure that these are understood by providers, users and regulators of payment systems and services.

108. Important efforts to build an infrastructure for the securities market have been put in place. However, the current arrangements need to be enhanced to allow for securities market transactions to be settled on an integrated basis. With the launch of the GSS, government securities custody issues and the primary market are progressing rapidly toward safety and efficiency. However, the integration of the different systems, the full immobilization and dematerialization of securities and secondary market trading are all important and open issues that authorities (CBTT, TTSEC, and the Ministry of Finance), market operators (CBTT and TTSE) and market participants (banks and broker/dealers) should address as a matter of urgency.

\section{Authorities' response and next steps}

109. Authorities had the opportunity to review this report and expressed agreement with its content. Their comments were accepted and incorporated in the document. In addition, the following information was also provided: "CPVII: Since the assessment in February 2005, the Bank has completed the Hot Site arrangements with backup facilities. The Business Continuity procedures have been drafted for finalization after testing. CP VIII: The Bank's Pricing Policy has been introduced. Effective June 2005 RTGS participants began to pay fees. The Bank continues to hold discussions with the commercial banks to introduce ways, including pricing, to discourage the use of checks for large value payments; CP IX: The criteria for access are stated in the Rules. Membership in the RTGS is intended for the

${ }^{23}$ This is currently the responsibility of the Ministry of Consumer Affairs. 
commercial banks initially and consideration will be given to the inclusion of other institutions subsequently; CP X: A formal User Group for the RTGS was formed and is active; Central Bank Responsibilities: Operating Rules and Regulations were signed by all participants in 2004. A Regulatory Policy Council was formed, chaired by the central bank, comprising the heads of the following regulatory agencies: The TTSEC; TTSE; DIC; and the Permanent Secretary, Ministry of Finance.” 